\title{
OVERVIEW OF TASMANIA'S OFFSHORE ISLANDS AND THEIR ROLE IN NATURE CONSERVATION
}

\author{
by Sally L. Bryant and Stephen Harris
}

(with one text-figure, two tables, eight plates and two appendices)

\begin{abstract}
Bryant, S.L. \& Harris, S. 2020 (9:xii): Overview of Tasmania's offshore islands and their role in nature conservation. Papers and Proceedings of the Royal Society of Tasmania 154: 83-106. https://doi.org/10.26749/rstpp.154.83 ISSN: 0080-4703. Tasmanian Land Conservancy, PO Box 2112, Lower Sandy Bay, Tasmania 7005, Australia (SLB*); Department of Archaeology and Natural History, College of Asia and the Pacific, Australian National University, Canberra, ACT 2601 (SH). *Author for correspondence: Email: sally.bryant181@outlook.com
\end{abstract}

Since the 1970s, knowledge of Tasmania's offshore islands has expanded greatly due to an increase in systematic and regional surveys, the continuation of several long-term monitoring programs and the improved delivery of pest management and translocation programs. However, many islands remain data-poor especially for invertebrate fauna, and non-vascular flora, and information sources are dispersed across numerous platforms. While more than $90 \%$ of Tasmania's offshore islands are statutory reserves, many are impacted by a range of disturbances, particularly invasive species with no decision-making framework in place to prioritise their management. This paper synthesises the significant contribution offshore islands make to Tasmania's land-based natural assets and identifies gaps and deficiencies hampering their protection. A continuing focus on detailed gap-filling surveys aided by partnership restoration programs and collaborative national forums must be strengthened if we are to capitalise on the conservation benefits islands provide in the face of rapidly changing environmental conditions and pressure for future use.

Key Words: Tasmanian islands, island conservation, island endemics, invasive species.

\section{INTRODUCTION}

Tasmania as a place is defined by islands: physically, culturally and ecologically. The enduring connection of Tasmania's Aboriginal people to offshore islands remains integral to their culture, and physical evidence of their occupation is found in cave sites, middens and artefacts, little of which has been documented. Many islands were named by the French during early scientific expeditions and are the type locations for plant and animal specimens sent back to the museums of Europe (examples in Bryant 2014, Harris 2014). Biologically, Tasmania's offshore islands contain sites of unique habitats, and in a context of uncertain environmental change, have become threatened species arks and refugia for species that are declining elsewhere (Moro et al. 2018). Islands through their limited size and isolation are the windows to evolution and are recognised globally for the role they play in conserving nature (Secretariat of the Convention of Biodiversity 2014). The interconnection between land and water is fundamental to island ecologies; for example, the nutrient-rich run-off from seabird and seal islands is an important driver for surrounding marine ecosystems and even phenomena such as 'Ashmole's halo' can regulate the population dynamics of seabird colonies through food depletion cycles (Gaston et al. 2007). The terrestrial biodiversity on islands is also supported by factors such as wind thrown drifts of algal wrack and from products of nesting seabirds (Polis \& Hurd 1996), which can often be important for islands with low primary productivity (Harris \& McKenny 1999). However, while we recognise the intrinsic link between island landmass and sea, an analysis of marine systems is beyond the scope of this paper. Instead, we provide a land-based perspective and draw on selected historical and contemporary information to highlight the importance of Tasmania's offshore islands to nature conservation and recommend measures needed if their values are to survive in the future.

Since the 1970s our knowledge of Tasmania's offshore islands has expanded greatly. This has been due to the island field surveys attributable to biologists in the founding years of the National Parks and Wildlife Service, new sources of funding, more recent surveys and better access to island information. Two key works, one by Brothers et al. (2001) providing information on 280 islands and the second by Harris et al. (2001) on the flora of 100 islands of the outer Furneaux Group resulted from extensive fieldwork from the 1980s. Systematic surveys of heathlands, saltmarshes, eucalypt forests and wetlands included investigation of these biomes on the larger offshore islands (for example, Kirkpatrick \& Harwood 1983). Knowledge of islands has continued to be supplemented through work under the Hamish Saunders Memorial Program (24 islands surveyed) and islands surveyed in anticipation of oil spill response (13 islands) (reports available DPIPWE Nature Conservation Report Series) and land management updates by the Tasmanian Aboriginal Centre (http://tacinc.com.au/ programs/land-management/).

To compile this overview, we used information from the sources mentioned and a range of institutional databases, geospatial systems, web inventories, the scientific literature and the authors' professional experience. Tasmania's reserve management plans contain topographical maps, title boundaries, lists of species, history of disturbances and management regulations (http://www.parks.tas.gov.au), with many older plans also summarising widely scattered reports such as those of early field naturalists' visits. Tasmania's State of the Environment Reports were used as sequenced documents for changes in coastal and marine habitats but 
these have not been updated for some time and not all are publicly available (RPDC 2006, TPC 2009).

Useful public databases include the systematic inventory of Tasmania's islands on the 'Islandshare' web portal (www. islandshare.net/), developed in 2012 by the Wildcare Friends of the Bass Strait Islands, Tasmanian Conservation Trust and Birdlife Tasmania and the Tasmanian Government's Natural Values Atlas (www.naturalvaluesatlas.tas.gov.au) which includes the Tasmanian Geoconservation Database, although this information is not island-specific.

\section{INVENTORY AND TENURE}

Mainland Tasmania has 5890 islands, islets, rock stacks and reefs located in the sea situated above the mean highwater mark (TASMAP 2006), not all of which are named. Of these, over 330 islands are greater than one hectare in size, 65 are greater than 20 hectares in size and Flinders Island $\left(1340.4 \mathrm{~km}^{2}\right)$ and King Island $\left(1093.9 \mathrm{~km}^{2}\right)$ are Australia's sixth and seventh largest islands. Tasmania's offshore islands are scattered around its entire coast, many occur in groups or clusters with the highest densities found in the
Bass Strait region especially the Furneaux area (fig. 1). On Tasmania's northern border, Rodondo Island is less than $10 \mathrm{~km}$ from the Victorian coast with the border running through Boundary Islet in the Hogan Group. To the south of Tasmania, Pedra Branca and Eddystone Rock lie $27 \mathrm{~km}$ from South East Cape and are the southernmost exposed land on Australia's continental shelf. A further $1,500 \mathrm{~km}$ to the south is subantarctic Macquarie Island which became part of Tasmania's territorial jurisdiction during the Van Diemen's Land proclamation in 1825.

Few of Tasmania's offshore islands are permanently settled. The larger King, Flinders, truwana-Cape Barren and Bruny islands have established population centres and some others, for example, Maria, Macquarie, Deal, Maatsuyker, Robbins, Three Hummock, Swan and lungtalanana-Clarke islands have staffed field stations, private houses or visitor accommodation. Many islands, however, retain a range of infrastructure such as lighthouses (pl. 1), airstrips, fences, tracks, homesteads and huts, reflecting current or past use and are visited for a variety of purposes.

From the 1970s onwards Tasmania's offshore islands were systematically reviewed for statutory protection. Maria, Schouten, Tasman, South Bruny and the Kent Group of

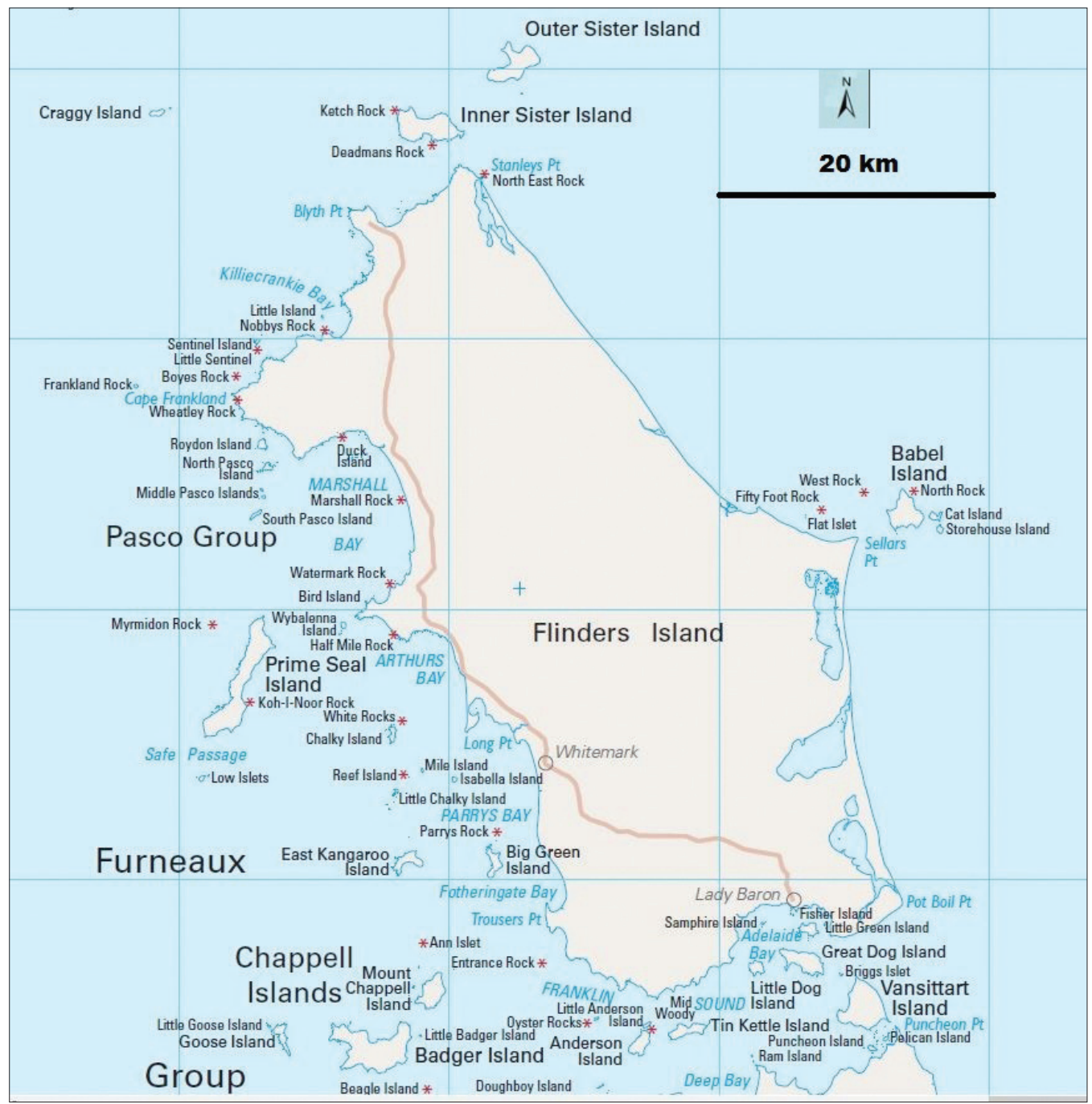

FIGURE 1 - Flinders Island showing density of surrounding islands. 
PLATE 1 - Maatsuyker Island showing lighthouse station and the Needle Rocks offshore.

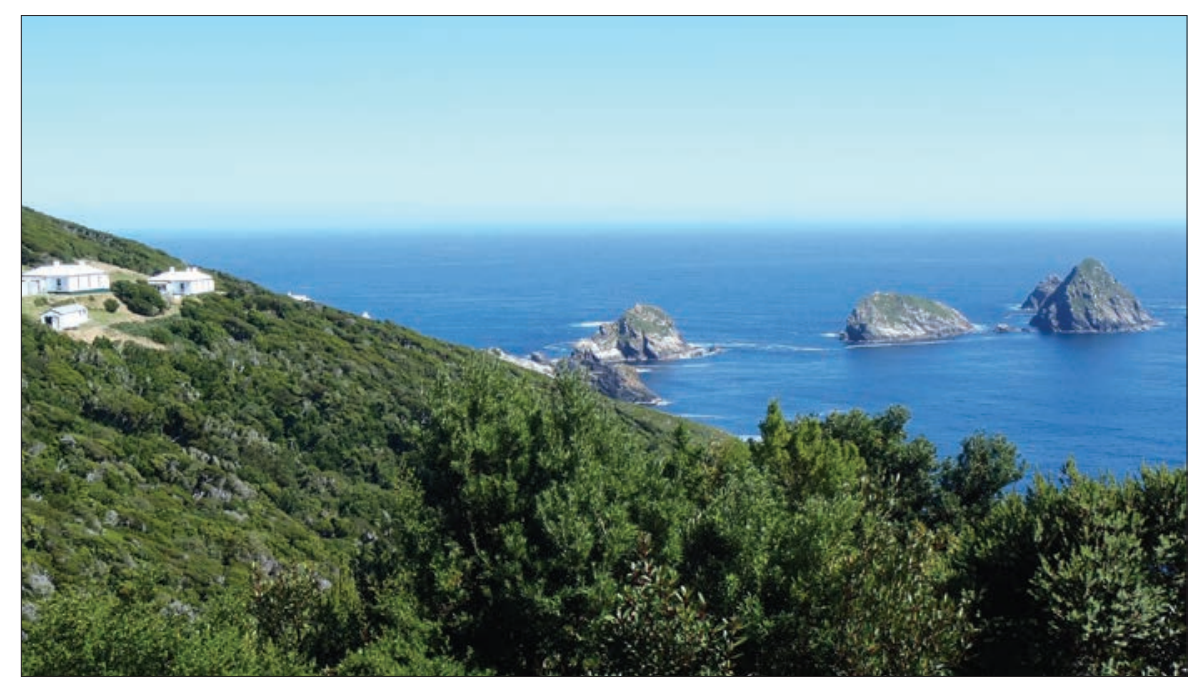

islands, were all incorporated into the boundary of existing national parks whereas other islands transitioned in status over time from unallocated Crown land or private lease, to Game Reserve, Conservation Area or Nature Reserve depending on their values. Macquarie Island, including Judge and Clerk and Bishop and Clerk islets, was proclaimed a Wildlife Sanctuary in 1933, a Conservation Area in 1971, State Reserve in 1972, Nature Reserve in 1978 and in 1997 was inscribed on the World Heritage List (PWS 2006) with its boundaries extended several times since to incorporate marine reserves. The Tasmanian Wilderness World Heritage Area incorporates numerous islands around the southwest coast, the larger being the Maatsuyker Island Group, De Witt, Ile du Golfe, Louisa Island, Hen and Chicken Islands, Pedra Branca, Mewstone, Eddystone Rock, Trumpeter Islet, Muttonbird Island, Breaksea Island and the Swainson Group (DPIPWE 2016).

Of Tasmania's larger offshore islands, 229 islands (more than $90 \%$ of them) have some level of statutory protection (table 1). This includes 75 islands previously classified as non-allocated Crown land but declared Conservation Areas through the Crown Lands Assessment Classification process in 2012. In 1995, as an act of reconciliation, the Tasmanian Government transferred control of seven islands (titimaTrefoil, Babel, Badger, Big Dog, Hummocky-Mt Chappell, Steep, lungtalanana-Clarke) and most of truwana-Cape Barren Island to the Aboriginal Land Council of Tasmania. Five of these islands are registered Indigenous Protected Areas (IPAs) managed by the Tasmanian Aboriginal Centre, which also manages 'Wybalenna' on Flinders Island and a small parcel of coastal land at Great Bay, Bruny Island. 'Murrayfield Station' on Bruny Island (4,097 ha) is owned and managed by the Indigenous Land Corporation.

Over thirty Reserve Management Plans and Indigenous Healthy Country Plans contain over 112 islands within their jurisdictional boundary; however, some plans (e.g., Small Bass Strait Island Reserves, Small North-East Islands and Small South-East Islands) have been in draft form for nearly two decades awaiting formal adoption (https://parks. tas.gov.au/about-us/managing-our-parks-and-reserves/ management-plans-reports).
TABLE 1 - Status of Tasmania's larger offshore islands.

\begin{tabular}{lc}
\hline Statutory Reserves & No. \\
\hline National Park & 62 \\
Conservation Area & 103 \\
Nature Reserve & 44 \\
State Reserve & 4 \\
Game Reserve & 9 \\
Nature Rec. Area, Historic Site & 2 \\
Indigenous Protected Area & 5 \\
Total & 229 \\
\hline & \\
\hline Multi or Private Tenure & No. \\
\hline Private Freehold & 12 \\
Multiple Land Tenure & \\
(Aboriginal, private, reserved) & 2 \\
Aboriginal Lands (Trefoil, Steep) & 23 \\
\hline Total & \\
\hline Source: http:/wwwislandsharent; https:/eatlas.or & \\
\hline
\end{tabular}

Source: http://www.islandshare.net/; https://eatlas.org.au/ node/ 1703 .

Tasmanian Parks and Wildlife Service is the land manager for islands or parts of islands reserved under the National Parks and Reserves Management Act 2002 and the Tasmanian Aboriginal Centre manages IPAs dedicated under the International Union for Conservation of Nature (IUCN). There is no single managing authority for unreserved islands in Tasmania; instead a range of state and local government agencies in accordance with Tasmania's Resource Management and Planning System (TPC 2009) are responsible for aspects of their management and protection. 


\section{NATURE CONSERVATION VALUES}

\section{Geo-conservation values}

Macquarie Island, Tasmania's only oceanic island, gained World Heritage status for its globally significant geological formation and is the only island in the world composed entirely of oceanic crust and rocks originating from deep below the Earth's surface (Williamson 1988). Macquarie Island is the only place where this exposed rock sequence is a uniquely complete section which can be studied in detail to better understand the processes of oceanic crust formation and plate boundary dynamics above sea-level (Comfort 2014).

All of Tasmania's nearer offshore islands were formed as the sea level rose after the Last Glacial, hence their geologies are often directly related to the adjacent mainland (Jennings 1959, Dixon 1996). King Island and the Fleurieu Group formed part of the peninsula northwest from Tasmania, and the Furneaux Group (and Kent and other island groups to the north) were part of the Bassian Rise land bridge between Tasmania and Victoria in the east.

Tasmania's islands are a range of hard and soft rock features, sandy dunes, spits, tombolos and isthmuses, with some displaying a range of significant geological features and diverse landforms (Banks 1993, Dixon 1996, Seymour et al. 2007). Features illustrating this diversity include: the tombolo on Actaeon Island, the tessellated pavements of Reid Rocks, the caves on Erith Island and De Witt, the lagoon on Southwest Island and the flowstone comprised of seal excrement on Judgement Rock.

Eberhard (2011) observed several bizarre-shaped weathered boulders on the coast of Inner Sister Island and identified the fabric of the granitic rock (mineral segregations and/or xenoliths) and presumed Pleistocene colluvial fans as features worthy of listing on the Tasmanian Geoconservation Database. On Hunter Island he identified the Cave Bay raised sea cave, Hunter Island cobble berms, and the Hunter Passage perched lagoons as being distinctive in the broader western Bass Strait region and also worthy of inclusion (Eberhard 2017).

On King Island, the Cambrian rocks along the City of Melbourne Bay foreshore contain globally significant lava pillows demonstrating seafloor volcanism, with other islands in northwest Tasmania, e.g., Robbins Island, displaying outstanding examples of beach ridge sequences marking at least two major phases of Quaternary activity. Maria Island's fossil cliffs, gulches, sea caves, raised shore platforms, blow hole and a razor-backed saddle-ridge are recognised as a globally unique set of features. The spectacular parallel dune systems enclosing brackish lagoons along the east coast of the Furneaux Islands, and the saline lagoon systems of truwuna-Cape Barren Island and lungtalanana-Clarke Island, are also of high geo-conservation significance (Dixon 1996).

Other islands of geo-significance are Black Pyramid for its Tertiary basaltic volcanic features, the sea caves and seal-related flowstone of Ile des Phoques, the geology of Pedra Branca and Eddystone Rock, and Tasman Island for its well-exposed columnar dolerite (pl. 2).

\section{Fauna values}

Over one third of Tasmania's land-based threatened fauna species occur on offshore islands (63 of 181 species, $35 \%$, appendix 1) demonstrating the significant role islands play in fauna conservation. Some islands are critical breeding sites or provide seasonal foraging habitat and some faunal groups, particularly island endemics or invertebrates, and found in only one island location. Even though the invertebrate values on Tasmania's offshore islands are becoming better known, this faunal group remains significantly under-surveyed. The coastal mollusc fauna on King Island contains at least 408 species with 78 being recorded for the first time by Grove and de Little (2014). Hamish Saunders Memorial Island surveys and Oil Spill Response surveys have targeted the

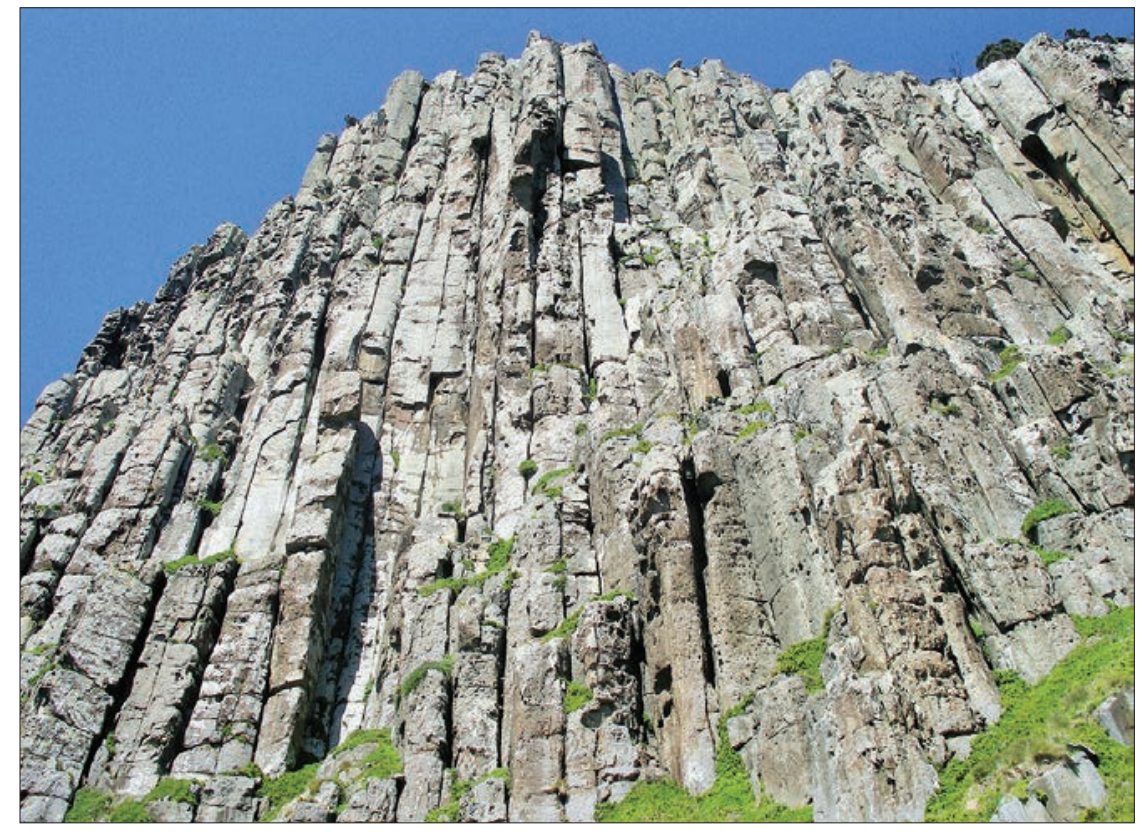

PLATE 2 - Dolerite structural columns on Tasman Island. 
PLATE 3 - Rare Tasman Island Cricket Tasmanoplectron isolatum.

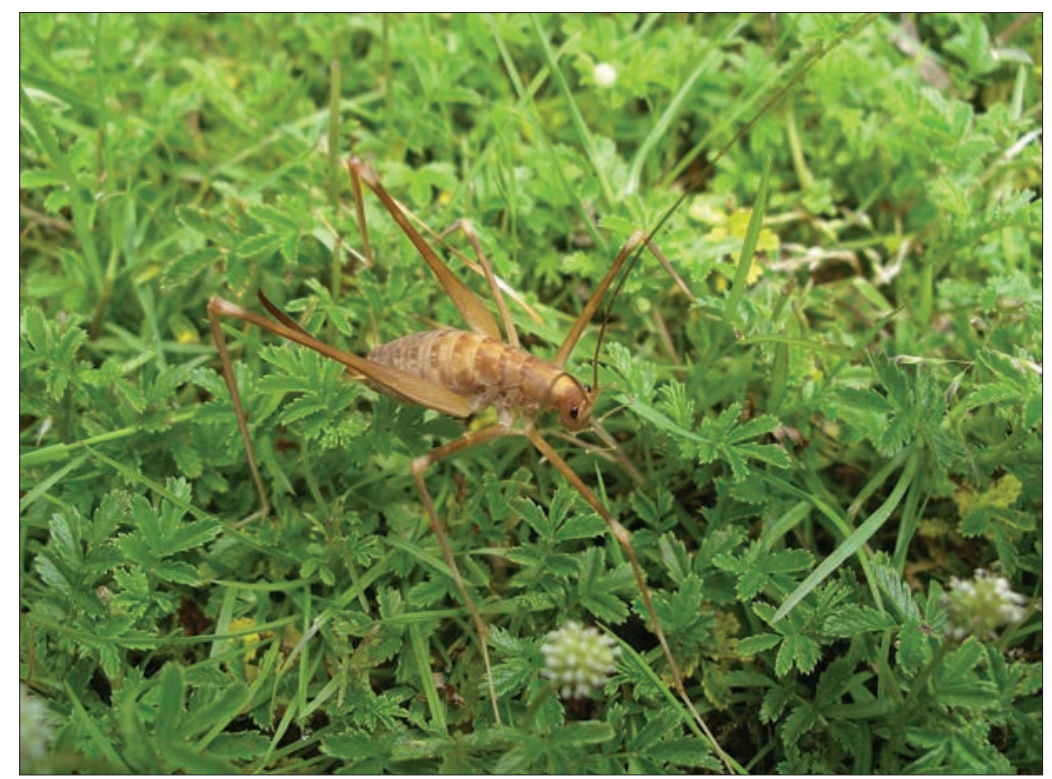

collection of invertebrates during their expeditions often focusing on threatened species or specific groups such as butterflies, grasshoppers, freshwater crayfish or molluscs, and invariably these surveys have resulted in new species finds and range expansions. For example, the invertebrate surveys conducted on Tasman Island identified a new snail species, Planilaoma? sp. nov. "Tasman Island”, a previously undescribed snail species, Pedicamista sp. "Southport", and the lodgement of voucher specimens of the rare Tasman Island Cricket Tasmanoplectron isolatum (Bryant \& Shaw 2006, pl. 3). New records of the molluscan Magilaoma penolensis and Scelidoropasp "Ridges Road" were made on Rodondo Island (Carlyon et al. 2015) and a species of stick insect was recorded for the first time in the eastern Bass Strait on Inner Sister Island (Harris \& Reid 2011). Unique assemblages of troglobitic cave invertebrates occur on Flinders Island and range extensions for other species such as the endemic Furneaux Burrowing Crayfish Engaeus martigener and Fringed Heath-blue Butterfly Neolucia agricola insulana (NCHD 2014) have been made there. The discontinuation of integrated island survey programs has meant that invertebrates are now often overlooked during short-stay visits and this gap in knowledge concurs with Mesibov's (2019) findings of a decrease in records of invertebrates lodged in museums and on databases since the turn of the century.

Islands are recognised globally as places with high levels of endemism and sites of extinction, and Tasmaniass islands follow this trend. In addition to the Thylacine Thylacinus cynocephalus and Tasmanian Emu Dromaius novaehollandiae diemenensis now extinct on mainland Tasmania, three island-specific endemic vertebrate species or subspecies have been destroyed on Tasmania's islands (Macquarie Island Parakeet Cyanoramphus erythrotis, Macquarie Island Rail Gallirallus philippensis macquariensis, King Island Emu Dromaius novaehollandiae minor) with a probable fourth, a Macquarie Island seal species, exterminated before it was scientifically described (Terauds \& Stewart 2009). Even more localised island extinctions have occurred. For example, on King Island, the King Island Emu, Fortyspotted Pardalote Pardalotus quadragintus, Spotted-tailed Quoll Dasyurus maculatus, Common Wombat Vombatus ursinus and Southern Elephant Seal Mirounga leonine are now extinct with a further 12 island species on the verge of extinction including the critically endangered King Island Scrub Tit Acanthornis magnus greenianus and King Island Brown Thornbill Acanthiza pusilla subsp. archibaldi (Donaghey 2003, TSS 2012, Webb et al. 2016). Other examples of regional extinctions are: Australian Sea Lions Neophoca cinerea no longer breed in Bass Strait after being eliminated on Christmas and New Year islands by harvesting in the nineteenth century, and an Australasian Gannet Morus serrator colony destroyed on Cat Island in the Furneaux Group before protective measures could be implemented (D. Pemberton, pers. comm).

The core breeding range for the Nationally Endangered Swift Parrot Lathamus discolour and Forty-spotted Pardalote centre on Flinders Island, Bruny Island and Maria Island and the Critically Endangered Orange-bellied Parrot Neophema chrysogaster depends on saltmarsh habitat on King Island and probably uses a number of northwest islands during its annual autumn migration (Bryant \& Jackson 1999). On Flinders, truwuna-Cape Barren and lungtalanana-Clarke islands (pl. 4), the saltmarsh communities, heathland and remnant forests are breeding sites for threatened or naturally restricted species such as the Dwarf Galaxias Galaxiella pusilla, New Holland Mouse Pseudomys novaehollandiae, Green and Gold Bell Frog Litoria aurea and other genetically or regionally distinct fauna species (e.g., Bass Strait Common Wombat Vombatus ursinus subsp. ursinus, Chappell Island Tiger Snake Notechis scutatus). Islands are also microcosms for bird species like Silvereye Zosterops or poor-dispersers such as scrub wren Sericornis sp. and thornbill Acanthiza sp. which all over the world have evolved into specific island forms (Kirkwood \& O'Connor 2010) and in Tasmania show distinct behavioural or morphological variation in the Bass Strait region (Bryant \& Carlyon 2013). Pedra Branca 


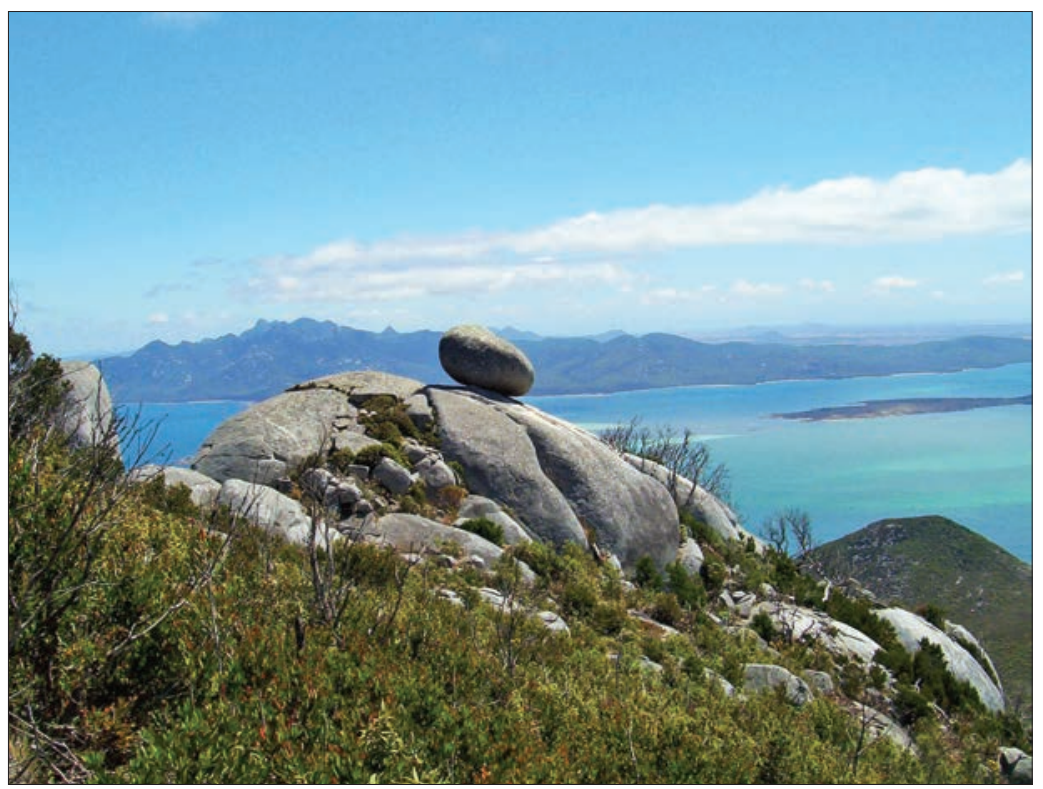

PLATE 4 - Northeast ridge on Mt Munro, truwuna-Cape Barren Island, looking across to Mount Strzelecki on Flinders Island.

islet (2.5 ha, pl. 5) is one of only three breeding sites for Endangered Shy Albatross Thalassarche cauta and critical habitat for the endemic Pedra Branca Skink Niveoscincus palfreymani, one of the rarest and most restricted reptiles in the world (Threatened Species Unit 2001).

The Ramsar wetlands of Lavinia (King Island), Logan Lagoon (Flinders Island) and truwuna-Cape Barren Lagoons are essential feeding sites for migratory waders during their annual East Asian migration (Woehler \& Ruoppolo 2010) and the islands in the Boullanger Bay-Robbins Passage area are the stronghold for 17 species of migratory and resident waders including Hooded Plover Thinornis rubricollis, Pied Oystercatcher Haematopus longirostris, Little Tern Sternula albifrons and Fairy Tern Sternula nereis (Bryant 2002). These values are recognised internationally with 29 Important Bird Areas (IBAs) designated wholly or partly on Tasmanian islands, the highest number of island-IBAs of any Australian state (Kirkwood \& O’Connor 2010).

Tasmania's islands are central to the ecology of all our land-breeding marine vertebrates including globally threatened albatrosses, giant petrel and burrowing seabird species and seal species (Bryant \& Jackson 1999). Over 60 species of seabird including massive aggregations of Shorttailed Shearwater Ardenna tenuirostris and Little Penguin Eudyptula minor breed on the Bass Strait islands, including those in the Hogan Group (Brothers et al. 2001, Carlyon et al. 2011). Sub-Antarctic Macquarie Island has an estimated biomass of 3.5 million breeding seabirds, predominantly penguins with some (e.g., Royal Penguin Eudyptes schlegeli, Macquarie Island Shag Leucocarbo purpurascens and several species of burrowing petrel) breeding only there (Bryant $\&$ Shaw 2007, Terauds \& Stewart 2009).

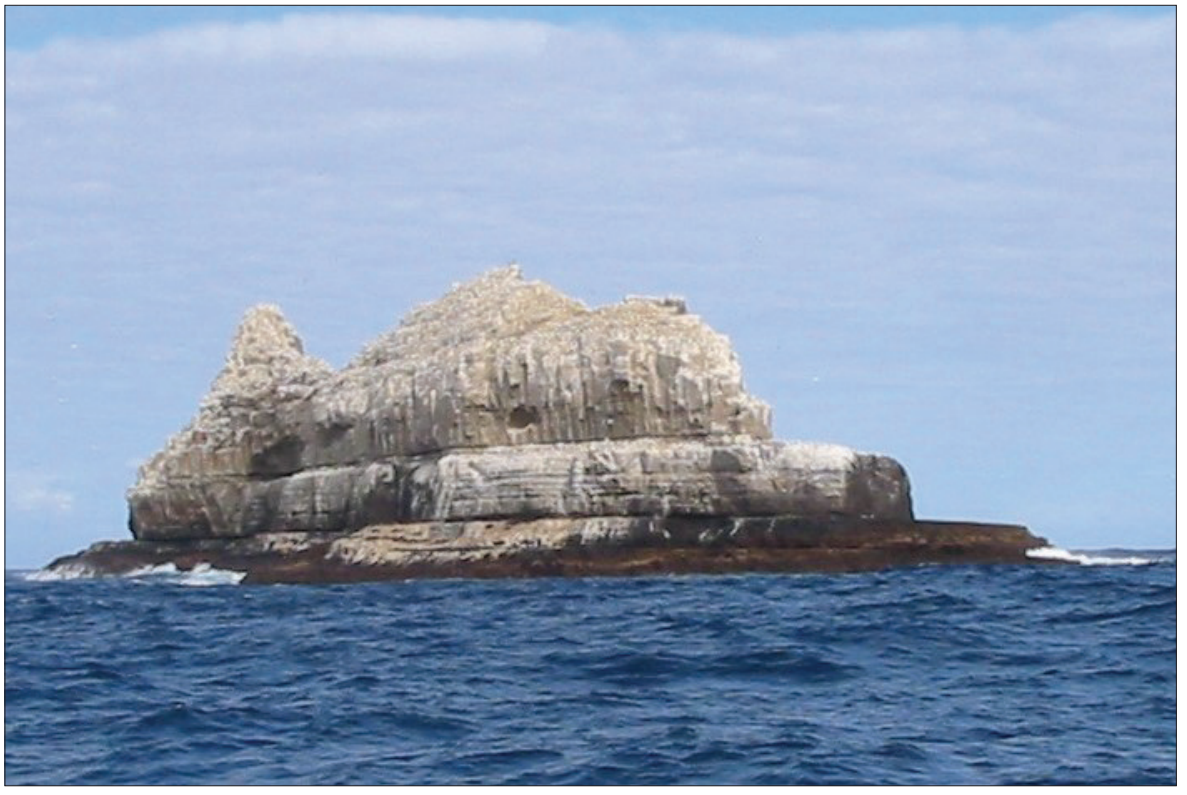

PLATE 5 - Pedra Branca Islet located $\sim 27 \mathrm{~km}$ off South East Cape. 


\section{Flora values}

The flora species on the littoral margins of the large islands and all low-lying islands are predominantly vagile and consequently tend to be widespread in occurrence. The autochthonous components of the floras on the larger islands are of special significance in some localities where the vegetation and floras are the result of climatic and fire factors peculiar to those sites. For example, Rodondo Island supports climax communities of Eucalyptus globulus, and Melaleuca armillaris as well as several plant taxa of regional biogeographic significance (Carlyon et al. 2015) which have evolved in the long absence of fire. Rodondo and Craggy islands also have one of the few indigenous Tasmanian occurrences of the shrub Paraserianthes lophantha, representing the eastern extremity of its natural distribution (Harris et al. 2001). Bass Strait islands are of particular biogeographical interest. The cloud forest on $\mathrm{Mt}$ Strzelecki on Flinders Island contains rainforest elements such as Atherosperma moschatum and a high proportion of the 137 species of liverworts and mosses recorded for the Strzelecki National Park (Harris et al. 2015). Such species assemblages assist in unravelling the palaeoenvironmental history of Bass Strait. The cloud forest on Mt Munro on truwuna-Cape Barren Island has the only Tasmanian stands of the tree Bedfordia arborescens within an unusual mosaic of plant communities (Harris \& Lazarus 2006).

The east shelf of Maria Island has an ecologically important forest boundary, where stands of pure Callitris rhomboidea abut Phyllocladus aspleniifolius-dominated rainforest, a situation attributable to an unusual combination of site factors, one of which appears to be the stripping of moisture by the rainforest from easterly sea mists. Such a sharp boundary between climax dry forest and climax cool temperate rainforest is significant in demonstrating the coincidence of forest types which may have been more common prior to the radiation of the eucalypts.
Many islands have one or more threatened plant species (appendix 2) or vegetation communities. For example, Bruny Island has approx. 39 state or nationally threatened plant species (Cochran 2003), and in 2019 a population of Acacia acinacea new to Tasmania was identified there (TLC 2019). In Bass Strait, Apium insulare and Bulbine crassa (pl. 6) represent taxa confined to the islands according to present knowledge, with so many other species such as Isopogon ceratophyllus and Leiocarpa supina occurring there as distribution range outliers.

Other island floras of national significance occur on Ile du Golfe, Maatsuyker Island and Flat Witch in the Tasmanian Wilderness World Heritage Area (Balmer et al. 2004) and the limestone flora on Prime Seal Island retains direct affinities with the Recherche Archipelago in Western Australia and the limestone coastal flora of South Australia (Harris et al. 2001). Deal Island in the Kent Group was visited in 1803 by the botanist Robert Brown who consequently made this the type locality for several plant taxa he collected there and first described.

Macquarie Island has a unique assemblage of vegetation communities and 48 plant species including four endemics (de Salas \& Baker 2018), with one of these endemics, the critically endangered cushion-forming Azorella macquariensis, a dominant species of the fjaeldmark community (Selkirk et al. 1990).

\section{INTRODUCTIONS AND TRANSLOCATIONS}

Islands are often regarded as stocking grounds for plants and animals declining elsewhere. Historically, several islands in Tasmania have had ad hoc releases such as Koala Phascolarctos cinereus, Forester Kangaroo Macropus giganteus and Cape Barren Geese Cereopsis novaehollandiae to Three Hummock Island (Bryant 2008) and Tasmanian Devil Sarcophilus harrisii to Badger Island in 1996 (DPIPWE 2010a). By
PLATE 6 - Island Leek Lilly Bulbine crassa, Neds Reef, near truwanaCape Barren Island.

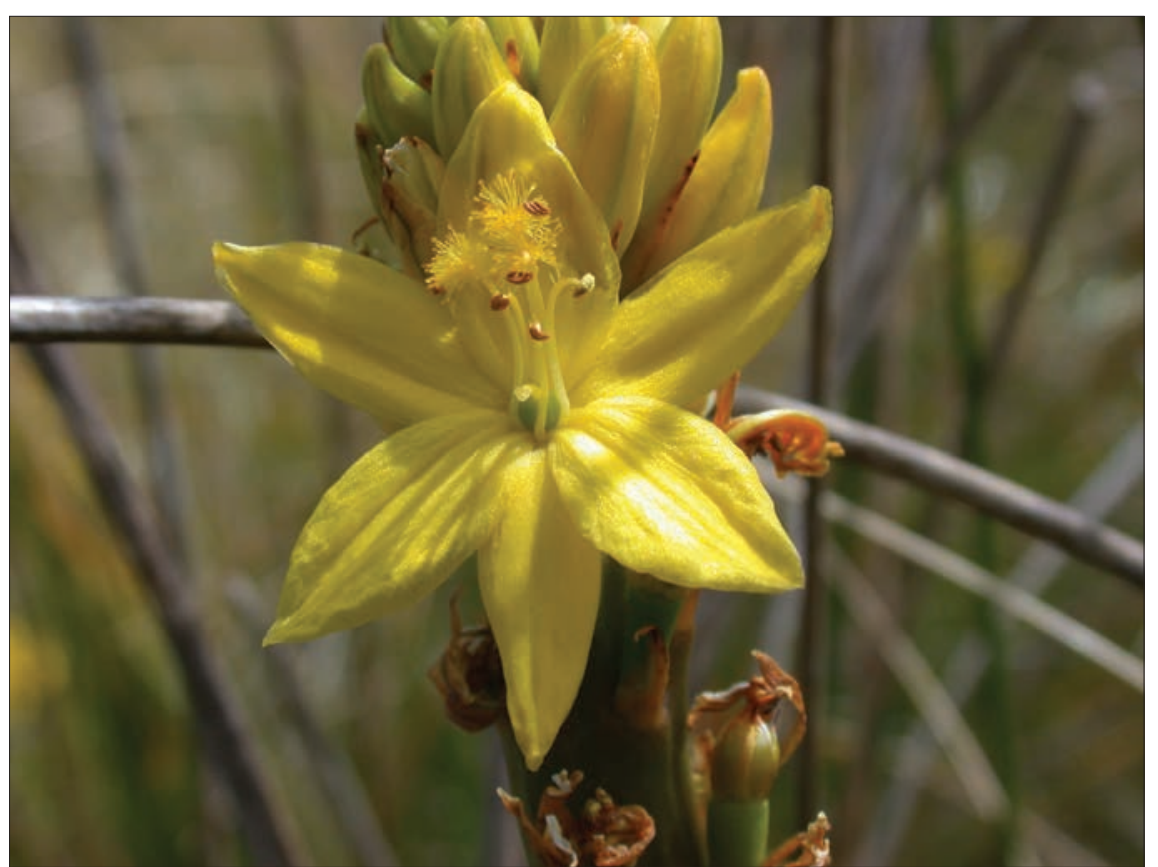


far the highest number of alien introductions have been to Maria Island with over 90 exotic plant species introduced as ornamental plants or for cultivation and 19 vertebrate species actively liberated or a legacy of European settlement (PWS 1998). Fallow Deer Dama dama were introduced to the pastures around Frenchs Farm but eradicated in 1998. Forester Kangaroo and Cape Barren Geese were introduced as they were declining in populations elsewhere and in 1968 Australian Emu Dromaius novaehollandiae were introduced in a failed experiment to recreate the extinct Tasmanian Emu but were removed in the 1980s (Rounsevell 1989). Between 1969 and 1972, over 760 individuals from 13 species of mammal and bird were liberated on Maria as a potential food source for Thylacine should they ever be re-discovered and need to be relocated there (National Parks \& Wildlife Service 1972). The legacy of these multiple introductions has compounded disturbance to Maria's ecosystem and imposed a burden of ongoing management to reduce several problematic species.

In 2012, Nationally Endangered Tasmanian Devils free of facial tumour disease were released on Maria Island to establish a free-ranging population under an approved translocation plan. Devils have subsequently successfully established and bred to a level where they are now being actively removed to re-populate mainland Tasmania sites (Wise et al. 2016). Tasmanian islands also provide opportunities for plant translocations though few have been undertaken to date. An ex-situ planting of the Critically Endangered endemic Epacris stuartii on Southport Island was undertaken in 2001 to prevent the species extinction should Phytophthora cinnamoni infect the only known wild population on nearby Southport Bluff. Recent suggestions of re-wilding some Bass Strait islands by reintroducing native extirpated predators to benefit threatened species is a novel approach which may become a recognised conservation tool of the future (Fielding et al. 2020).

\section{ISLAND MONITORING PROGRAMS}

It is difficult to assess the trends in the condition of Tasmania's offshore island environments as no baseline indicators are in place (Tasmanian Planning Commission 2009). However, at least 50 islands undergo repeat site visits to assess vertebrate breeding populations or monitor numbers; the most regularly visited are shown in table 2 . One of the longest running wildlife monitoring programs in the world is on Fisher Island, where Short-tailed Shearwaters have been monitored annually since 1947 when first established by the ornithologist Dominic Serventy (Bradley et al. 2008).

TABLE 2 -Vertebrate assessments on Tasmanian islands. ${ }^{1,2}$

\begin{tabular}{|c|c|}
\hline Species or group & Islands monitored \\
\hline $\begin{array}{l}\text { Australian fur seal breeding and haul-out } \\
\text { sites }\end{array}$ & $\begin{array}{l}\text { Maatsuyker, De Witt, Needles, Walker, Little Witch, Pedra Branca, Mewstone, } \\
\text { Sugarloaf Rocks, Tasman, Hippolyte Rock, Albatross, Black Pyramid, Tenth, } \\
\text { Judgement Rocks, West Moncoeur, Bass Pyramid, Wright Rocks, Reid Rocks, East } \\
\text { Moriarty, West Moriarty Rocks; Bull Rocks, Ile des Phoques, Bruny, The Friars }\end{array}$ \\
\hline Shy Albatross & Albatross, Mewstone, Pedra Branca \\
\hline $\begin{array}{l}\text { Albatrosses ( } 4 \text { species), Giant Petrel ( } 2 \\
\text { species), burrowing seabirds ( } 21 \text { species }) \text {, } \\
\text { penguins ( } 4 \text { species), seals ( } 5 \text { species) }\end{array}$ & Macquarie \\
\hline Australasian Gannett & Pedra Branca, Eddystone, Black Pyramid, Bass Pyramid, Cat \\
\hline Little Penguin & $\begin{array}{l}\text { Bruny, Ninth, Passage, Forsyth, King, Councillor, Georges Rocks, Diamond, Maria, } \\
\text { Schouten, Huon, Tasman, De Witt, Maatsuyker, Louisa, Flinders }\end{array}$ \\
\hline Pacific Gull & Goose, Flinders \\
\hline $\begin{array}{l}\text { Shorebirds ( } \sim 17 \text { resident and migratory } \\
\text { species) }\end{array}$ & $\begin{array}{l}\text { Robbins, Walker, Perkins, Kangaroo, Wallaby Islets, Montague, Maria, Flinders, } \\
\text { Cape Barren, King, Bruny }\end{array}$ \\
\hline Forty-spotted Pardalote, Swift Parrot & Maria, Flinders, Bruny including Partridge \\
\hline Orange-bellied Parrot & King, Robbins, Walker, Perkins, Port Davey islands \\
\hline Eagles ( 2 species) & Most regularly Maria, Bruny, Flinders \\
\hline $\begin{array}{l}\text { Short-tailed Shearwater, Cape Barren Goose, } \\
\text { Brown Quail }\end{array}$ & $\begin{array}{l}\text { Maatsuyker, Fisher, Big Green, East Kangaroo, Little Green, Great Dog, Little Dog, } \\
\text { Chappell, Bruny, Tasman, Flinders, Vansittart, Tin Kettle, Woody, East Kangaro,, } \\
\text { Goose, Isabella, Inner Sister, Badger }\end{array}$ \\
\hline Pedra Branca Skink & Pedra Branca \\
\hline Common Pheasant & Hunter group, Furneaux group, King \\
\hline Macropods, Brush-tailed Possum & Maria, Flinders, King \\
\hline
\end{tabular}

${ }^{1}$ Visits may be irregular or repeat visits for breeding or population assessments, or determining harvesting quotas, etc.

2 Referenced from multiple sources including back issues of Game Tracks (https://dpipwe.tas.gov.au/Documents/Game-tracks.pdf), Driessen \& Hocking (2008). 
Short-tailed Shearwater, Cape Barren Geese and Brown Quail Coturnix ypsilophora are monitored on several islands in the Furneaux Group to determine harvesting quotas (Wildlife Management Branch 2010) and over 20 islands and rock stacks are surveyed regularly for Australian Fur Seal Arctocephalus pusillus activity (Bryant \& Jackson 1999 , Kirkwood et al. 2010). Shorebirds are surveyed seasonally on multiple islands in Boullanger Bay area, with over 70 islands having been surveyed repeatedly for these species during the past 30 years (Bryant 2002, Woehler \& Ruoppolo 2010). Critical research on Shy Albatross has been undertaken on Albatross Island, Mewstone and Pedra Branca for over 20 years as part of this species recovery efforts, and monitoring programs on Macquarie Island have been critical to determine population numbers pre-and post-pest eradication programs (Springer 2018). Another Macquarie Island research program monitoring the impact of European Rabbit Oryctolagus cuniculus browsing on sensitive vegetation has continued since 1981 (Whinam \& Shaw 2018).

\section{THREATS}

\section{Invasive species}

Invasive species are an insidious threat that impact most of Tasmania's offshore islands and often go unnoticed and unmanaged. While no current comprehensive information exists on the number of Tasmanian islands impacted by invasive species, at least 70 have been recorded with introduced mammal species (Brothers et al. 2001, Terauds 2005, Pfennigwerth 2008, TPC 2009). The most commonly recorded are European Rabbit Oryctolagus cuniculus, feral Cat Felis catus, Black Rat Rattus rattus, House Mouse Mus musculus and a variety of domestic stock. Feral Pigs Sus scrofa are widespread on parts of Flinders Island since their introduction in the early 1880s (Statham \& Middleton 1987) and recent Fallow Deer Dama dama have yet to be removed from the wild on Bruny Island and King Island. Many introduced bird species occur on islands often liberated for hunting or pleasure such as Ring-necked (Common) Pheasant Phasianus colchicus, Turkey Meleagris gallopavo and Indian Peafowl Pavo cristatus on Flinders Island and King Island.

Weeds are widespread on even more offshore islands, many being either cosmopolitan or ruderal species or possibly benign in their ecological impacts. Weeds that pose problems include, for example: African Boxthorn Lycium ferocissimum, Gorse Ulex europaeus, Canary Broom Genista monspessulana, Spanish Heath Erica lusitanica, Shining Coprosma Coprosma repens, Blackberry Rubus fruticosus and Sea Spurge Euphorbia paralias. Marram Grass Ammophila arenaria was introduced to Tasmania to stabilise sand dunes and is now widespread and well-established on the sandy coasts of most near onshore islands. Macquarie Island has seven alien plant species, two of which Anthoxanthum odoratum and Rumex crispus have already been removed (de Salas \& Baker 2018).
The occurrence of the water mould Phytophthora cinnamomi is a significant cause of degradation in heathland communities on larger islands such as Schouten Island, Three Hummock Island, Flinders Island, truwuna-Cape Barren Island and lungtalanana-Clarke Island where it infests swathes of heathland. The result is the selective mortality of plants in the susceptible families, especially Proteaceae, Myrtaceae, Ericaceae and Fabaceae.

Until recently, vertebrate control programs on islands have been largely ad-hoc with mixed success. However, over the past decade Tasmania has significantly improved its eradication methodologies with several now cited as exemplars of success. Pest management on Macquarie Island had systematically eradicated Weka Gallirallus australis by 1988, feral Cats by 2002, and finally Rabbits, Black Rat and House Mouse by 2014 in a multipronged multi-species approach (Springer 2018, pl. 7). Feral Cats have been eradicated from Tasman Island and Wedge Island (Robinson et al. 2015, Robinson \& Gadd 2020), House Mouse from Fisher Island (S. Robinson, pers. com.) and Black Rat from Big Green Island (Robinson \& Dick 2020) with planning underway on other islands. The Bruny Island Cat Management program commenced in mid-2016 and has already significantly reduced cat numbers aiming to meet the Commonwealth's target of being one of Australia's Five Cat Free Islands (Allan 2019). Several feasibility plans have been prepared for the removal of feral Pig Sus scrofa from Flinders Island, but none have yet to secure funding. The improved success of government-led eradication efforts has been largely due to a combination of

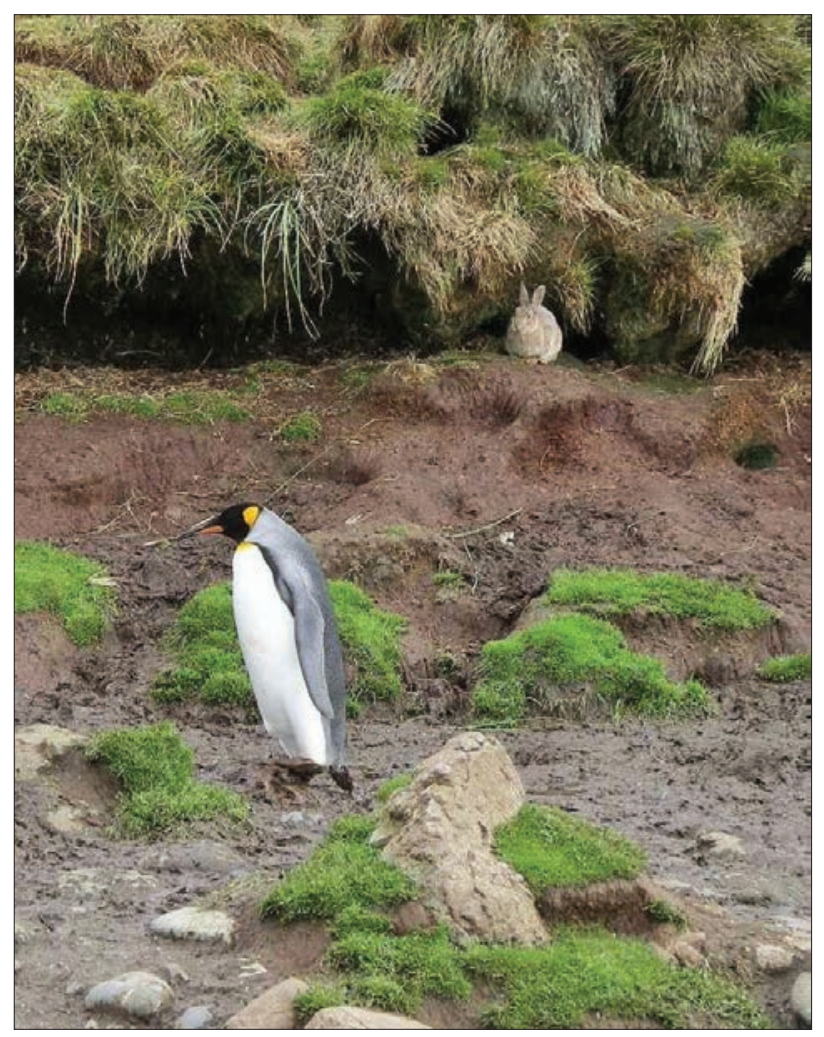

PLATE 7 - European Rabbit denuding the slopes of Macquarie Island prior to eradication. 


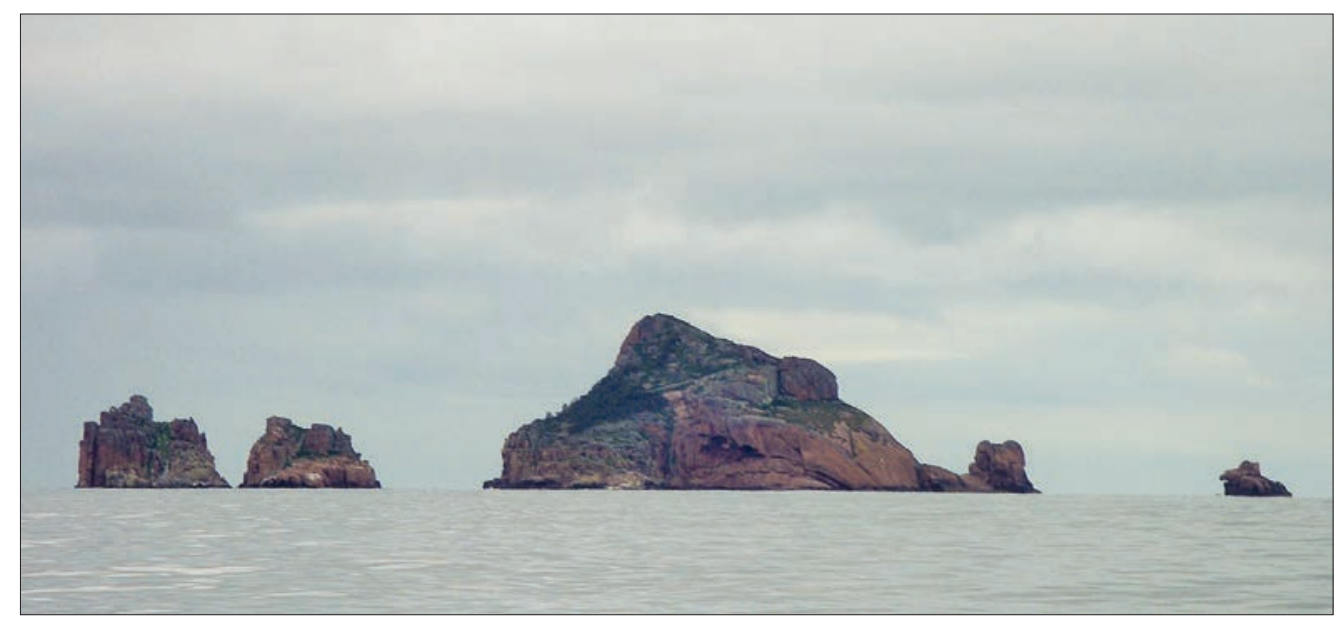

PLATE 8 - Taillefer Rocks off Schouten Island, Freycinet National Park.

better planning, improved technology, aid from volunteer labour and philanthropic financial support (Springer 2018, Robinson \& Dick 2020).

\section{Uncontrolled access}

Inappropriate or uncontrolled access to islands can cause disturbance to sensitive breeding species, and increase the risk or spread of invasive species, disease and fire. Several Tasmanian islands restrict public access unless authorised by permit (Macquarie Island, Judgement Rocks, North East Isle, South West Isle, Vissher Island, Ile de Phoques, Albatross Island, Rodondo Island and others) and partial restrictions apply to a number of islands within Freycinet National Park (The Nuggets, Refuge Island, Promise Rock, Lemon Rock, HalfLemon Rock, Eastern Rock and Taillefer Rocks (pl. 8)).

A government protocol is in place which identifies 12 steps to preventing pests, weeds and diseases spreading to Tasmania's islands (http://www.islandshare.net/Documents/ Island_Biosecurity_Guide.pdf), with additional biosecurity measures recommended for islands in Tasmania's Southwest Wilderness Area (Mallick \& Driessen 2009). Minimal impact guidelines have been prepared for sea kayakers to ensure that sensitive areas are not disturbed or compromised during recreational visits which for some even remote islands have become a constant summer destination (D. Pemberton, pers. com.). Rigorous biosecurity procedures are in place for Macquarie Island and these are included as part of the guidelines for tourist operations to the island (PWS 2006, http://www.parks.tas.gov.au/).

\section{Climate change}

Australia's most recent species extinction resulting from the loss of habitat by sea level rise (Woinarski et al. 2018) was the endemic Bramble Cay Melomys Melomys rubicola, from the northern Great Barrier Reef. More than 1,440 km of Tasmania's coast is subject to flooding, and over $975 \mathrm{~km}$ of shoreline at risk of erosion, sand dune mobility, rock falls and slumping as a result of sea level rise and more frequent storm surges (Sharples 2006, DPIPWE 2010b). A rise in mean sea level due to global warming of between $5 \mathrm{~cm}$ and $14 \mathrm{~cm}$ for Tasmania is projected to occur by 2030 meaning 1 -in-100-year storm tide events could occur as frequently as once every 50 years, and are therefore likely to impact all low-lying Tasmanian islands. Southeastern Tasmania is predicted to experience the greatest increase in sea surface temperature and in Mercury Passage the rise of $1.6^{\circ} \mathrm{C}$ recorded in the past 50 years, is already three times the average rate of global warming (ACE CRC 2010, Parsons 2011). Ocean acidification and reduced calcification is anticipated to cause increased erosion of coral reefs like those off the islands in the Kent Group, having potential consequences for the marine food chain (TPC 2009). Australia-wide nearly 20\% of migratory bird species are likely to be affected through the loss of habitat due to sea level rise and coastal development (Mallon 2007). Loss of frontline beach foredune, shrubland communities and tussock grassland will reduce breeding habitat for marine seabirds, most of which have high site fidelity. Sea level has fluctuated during the Holocene and there is evidence of fossil shorelines many metres above the current high-water mark. The response of the terrestrial biota to such sea level changes is poorly understood, although the ameliorative effects of higher sea levels in creating new habitats has been investigated by Prahalad and colleagues on coastal saltmarshes. They use predictive models to anticipate where new habitat may be created under different sea level change scenarios (e.g., Prahalad et al. 2012, Prahalad \& Pearson 2013). Seminal research on the Macquarie Island Cushion Plant identified the cause of its decline was due to a climatic shift, exposing this unique cold, wet adapted species to prolonged periods of drying (Whinam \& Shaw 2018). The long-term monitoring of island species in remote environs is often pivotal for identifying the impact of insidious threats and recommending recovery actions that could benefit groups of co-located species (e.g., response of burrow nesting petrels to climate change in Brothers $\&$ Bone 2008). 


\section{ISLAND PARTNERSHIPS}

Volunteers and philanthropic partnerships remain instrumental in helping deliver a range of conservation initiatives on Tasmania's islands and are pivotal for ongoing success (Bryant \& Copley 2018). Groups such as the Bruny Island Environmental Network are community-based collectives that assess policy, development applications and all manner of local issues to ensure transparency and protection of island values. Since the 1970s Birdlife Tasmania volunteers have collected bird data on species distribution, sensitive bird breeding islands (www.birdlife.org.au/locations/birdlifetasmania) and assisted in island monitoring and eradication efforts. In 2020 Wildcare Tasmania (www.wildcaretas.org. $\mathrm{au} /$ ) had 11 registered island-specific Wildcare groups contributing to weed removal, track or heritage restoration or caretaker positions on islands. Some, for example, the Friends of Bass Strait Islands manage weed removal on ten outer Furneaux Islands, and the Friends of Maatsuyker Island undertake lighthouse preservation, caretaker duties, weed removal and seabird monitoring, often at their own expense (Bryant \& Copley 2018). The Cradle Coast Authority is aiming to protect shorebird species on Three Hummock Island by removing feral Cats and controlling Sea Spurge and other weeds in the Robbins Passage area.

The Tasmanian Aboriginal community including the Tasmanian Aboriginal Centre and the people on truwuna-Cape Barren Island, Flinders Island and Bruny Island have formed strong partnerships with a range of government and private bodies to undertake research and collaborate on land management projects on their islands, including with Australian National University researchers, allowing the investigation of palaeoenvironments reconstructed from sediment and pollen cores (McWethy et al. 2017).

Since 1989 the Princess Melikoff Trust has financially supported government marine mammal conservation by funding surveys of seal breeding and haul-out sites on numerous islands around Tasmania, and from 2003 to 2017 a partnership with the Hamish Saunders Memorial Island Survey Program facilitated multi-disciplinary expeditions to 24 offshore islands and the publication of results. While several commercial businesses (e.g., Maria Island Walk (www.mariaislandwalk.com.au)) support local island initiatives, the most influential island partnership to date has been with Pennicott Wilderness Journeys, who make sizeable donations from the Pennicott Foundation which have been pivotal in the success of so many island management programs (https:/www.pennicottfoundation. org.au/projects/).

Collaborating in international symposia like the Small Island Developing States (www.first.org/events/symposium/ nadi2019/) and the National Island Arks Symposia (http:// islandarks.com.au/) are instrumental for the sharing of knowledge across multi-disciplines dealing with island management including the role of local communities and indigenous practice. Participation in collaborative forums such as these is essential for island managers to discuss commonly shared problems as islands become increasingly more attractive for developments and expanding populations at the cost of their natural values.

\section{CONCLUSIONS}

Tasmania's offshore islands contain globally unique natural values and play a significant role in nature conservation, but their ongoing management is necessary to prevent degradation and local species extinction. A national review by Ecosure (2009) identified 15 Tasmanian islands among Australia's top 100 most conservation important islands greater than 200 ha in size. While those identified are significant, size is not a valid criterion to determine conservation value as most, even small, islands can contain inherently unique assemblages. Management of islands requires a multi-disciplinary approach supported by comprehensive evidence and a decision support system (Lohr et al. 2018) that can simplify the myriad of possible actions involved in protecting island species. One such system designed by Helmstedt et al. (2016) for island invasive species eradication factored in a range of attributes including likelihood of success and cost-effectiveness, and demonstrated that for a fixed budget, a higher conservation benefit could be achieved across multiple islands. Assigning a set of baseline indices for island condition are also essential if we are to track the ecological health of islands in response to management programs or pressures from future use or climate change.

Due to competing demands and costs associated with their access and management, islands seldom receive the timely attention they deserve, leaving them exposed to existing and emerging threats including inappropriate development. Designating islands that contain important nature conservation values as 'Matters of National Environmental Significance' under the Commonwealth Environment Protection and Biodiversity Conservation Act 1999 (EPBC Act) has been proposed by Woinarski et al. (2018). This mechanism could be strengthened further by the listing of 'important island populations' as threatened communities or threatened ecosystems under Tasmania's Nature Conservation Act 2001. If important islands were designated as a 'threatened ecological community' it might focus attention and justify the direction of additional resources towards their management.

With improving knowledge, technology and increased volunteer-philanthropic support, invasive species are being reduced with greater efficiency providing island systems time to recover. However, these efforts need to be supported and expanded if we are to retain our unique island ecologies in the future.

\section{ACKNOWLEDGEMENTS}

This paper is based on a keynote address given by the lead author at the Island Arks Symposium in 2012. Mr Keith Springer, Dr Justine Shaw, Mr Grant Dixon and Mr Christian Bell kindly provided advice at that time. We thank Dr David 
Pemberton and Dr Michael Driessen for their review of this manuscript and very helpful suggestions. Ms Eve Lazarus assisted with the compilation of appendix 2 . All photos are those of the authors.

\section{REFERENCES}

ACE CRC 2010: Climate Futures for Tasmania: extreme events: the summary. Antarctic Climate and Ecosystems Cooperative Research Centre, Hobart, Tasmania: 12 pp.

Allan, K. 2019: Bruny Island cat management project. Project update Feb 2019-July 2019. Kingborough Council: 14 pp (www. kingborough.tas.gov.au/wp-content/uploads/2020/07/ Bruny-cat-management-update_Oct-2019.pdf).

Balmer, J., Whinam, J., Kelman, J., Kirkpatrick, J.B. \& Lazarus, E. 2004: A review of the floristic values of the Tasmanian Wilderness World Heritage Area. Nature Conservation Report 2004/3. DPIWE, Hobart, Australia: 133 pp.

Banks, M.R. 1993: Reconnaissance geology and geomorphology of the major islands south of Tasmania. Report to the Department of Parks, Wildlife and Heritage, Tasmania: $40 \mathrm{pp}$.

Bradley, J., Skira, I. \& Wooller, R. 2008: A long-term study of Short-tailed Shearwaters Puffinus tenuirostris on Fisher Island, Australia. Ibis 133: 55-61.

Brothers, N. \& Bone, C. 2008: The response of burrow-nesting petrels and other vulnerable bird species to vertebrate pest management and climate change on sub-Antarctic Macquarie Island. Papers and Proceedings of the Royal Society of Tasmania 42(1): 123-148.

Brothers, N., Pemberton, D., Pryor, H. \& Halley, V. 2001: Tasmania's Offshore Islands: Seabirds and Other Natural Features. Tasmanian Museum and Art Gallery, Hobart: 643 pp.

Bryant, S.L. 2002: Conservation assessment of beach nesting and migratory shorebirds in Tasmania. Natural Heritage Trust Project NWP 11990, Nature Conservation Branch, Hobart: $123 \mathrm{pp}$

Bryant, S.L. (ed) 2008: Three Hummock Island: 2006 flora and fauna survey. Hamish Saunders Memorial Trust, New Zealand and Resource Management \& Conservation, DPIW, Hobart, Nature Conservation Report Series 08/03: 54 pp.

Bryant, S.L. 2014: Birds. In Hansen, A. \& Davies, M. (eds): Library at the End of the World: natural science and its illustrators. Royal Society of Tasmania, Hobart: 148-168.

Bryant, S.L. \& Carlyon, K. 2013: Birds of Inner Sister Island, Eastern Bass Strait. Tasmanian Bird Report 35:1-6.

Bryant, S.L. \& Copley, P.B. 2018: Partnerships for island conservation: it's all about people. In Moro, D., Ball, D. \& Bryant, S.L. (eds): Australian Island Arks: Conservation, Management and Opportunities. CSIRO Publishing, Clayton South, Victoria: $177-190$.

Bryant, S.L. \& Jackson, J. 1999: Tasmania's Threatened Faune Handbook: Where, What and How to Conserve Tasmania's Threatened Animals. Threatened Species Unit, Parks and Wildlife Service, Tasmanian Government Printer, Hobart: 426 pp. (https://dpipwe.tas.gov.au/conservation/threatenedspecies-and-communities/publications-forms-relatedinformation/tasmanias-threatened-fauna-handbook).

Bryant, S.L. \& Shaw, J. (eds) 2006: Tasman Island: 2005 flora and fauna survey. Hamish Saunders Memorial Trust, New Zealand and Biodiversity Conservation Branch, DPIW, Hobart, Nature Conservation Report Series 06/01: 49 pp.

Bryant, S.L. \& Shaw. J.D. 2007: Threatened species assessment on Macquarie Island, Voyage 5, April 2007. Report to Biodiversity Conservation Branch, DPIW, Tasmania: 21 pp. (https://dpipwe.tas.gov.au/Documents/MacquarieIsland-Report-2007.pdf).
Carlyon, K., Pemberton, D. \& Rudman, T. 2011: Islands of the Hogan Group, Bass Strait: Biodiversity and Oil Spill Response Survey. Resource Management and Conservation Division, DPIPWE, Hobart, Nature Conservation Report Series 11/03: 53 pp.

Carlyon, K., Visoiu, M., Hawkins, C., Richards, K. \& Alderman, R. 2015: Rodondo Island, Bass Strait: Biodiversity \& Oil Spill Response Survey, January 2015. Natural and Cultural Heritage Division, DPIPWE, Hobart. Nature Conservation Report Series 15/04: 59 pp

Cochran, T. 2003: Managing Threatened Species and Communities on Bruny Island. Threatened Species Unit, Department of Primary Industries, Water and Environment, Tasmania: $172 \mathrm{pp}$.

Comfort, M. 2014: Macquarie Island World Heritage Area Geoconservation Strategy. Resource Management and Conservation Division, Department of Primary Industries, Parks, Water and Environment, Hobart. Nature Conservation Report Series 14/2: 48 pp.

de Salas, M.F. \& Baker, M.L. 2018: A Census of the Vascular Plants of Tasmania, including Macquarie Island. Tasmanian Herbarium, Tasmanian Museum and Art Gallery, Hobart: $156 \mathrm{pp}$.

Dixon, G. 1996: A reconnaissance inventory of sites of geo-conservation significance on Tasmanian islands. Report to Parks \& Wildlife Service, Tasmania: $30 \mathrm{pp}$.

Donaghey, R. (ed.) 2003: The fauna of King Island: A guide to identification and conservation management. King Island Natural Resource Management Group Inc. King Island: $152 \mathrm{pp}$

Driessen, M.M. \& Hocking, G.J. 2008: Review of Wildlife Monitoring Priorities. Nature Conservation Report 08/02. Department of Primary Industries and Water, Tasmania: $58 \mathrm{pp}$.

DPIPWE 2010a: Draft Recovery Plan for the Tasmanian Devil (Sarcophilus harrisii). Department of Primary Industries, Parks, Water and Environment, Hobart: 55 pp. (https:// dpipwe.tas.gov.au/Documents/Draft-Tasmanian-DevilRecovery-Plan.pdf)

DPIPWE 2010b: Vulnerability of Tasmania's natural environment to climate change: an overview. Unpublished report. Resource Management and Conservation Division, Department of Primary Industries, Parks, Water and Environment, Hobart: 90 pp.

DPIPWE 2016: Tasmanian Wilderness World Heritage Area Management Plan 2016, Department of Primary Industries, Parks, Water and Environment, Hobart: 240 pp.

Eberhard, R. 2011: Geodiversity. In Harris, S. \& Reid, A. (eds): Inner (West) Sister Island Scientific Expedition 2010. Hamish Saunders Memorial Trust, New Zealand and Resource Management and Conservation Division, DPIPWE. Hobart, Nature Conservation Report Series 11/2: 19-26.

Eberhard, R. 2017: Aspects of geodiversity on Hunter Island: four Quaternary age Geosites. In Natural and Cultural Heritage Division: South Hunter and Stack Island Natural and Cultural Values Survey. Hamish Saunders Memorial Trust, New Zealand and the Natural and Cultural Heritage Division, DPIPWE. Hobart, Nature Conservation Report 17/4: 69-70.

Ecosure 2009: Prioritisation of high conservation status of offshore islands. Report to the Australian Government Department of the Environment, Water, Heritage and the Arts. Ecosure, Cairns, Queensland: $387 \mathrm{pp}$.

Fielding, M.W., Buettel, J.C. \& Brook, B.W. 2020: Trophic rewilding of native extirpated predators on Bass Strait Islands could benefit woodland birds. Emu - Austral Ornithology 120(3): 260-262.

Gaston, A.J., Ydenberg, R.C. \& Smith, G.E.J. 2007: Ashmole's halo and population regulation in seabirds. Marine Ornithology 35: 119-126. 
Grove, S. \& de Little, R. 2014: The coastal marine mollusc fauna of King Island, Tasmania. Papers and Proceedings of the Royal Society of Tasmania 148: 17-42.

Harris, S. 2014: Vascular Plants. In Hansen, A. \& Davies, M. (eds): Library at the End of the World: natural science and its illustrators. Royal Society of Tasmania, Hobart: 22-49.

Harris, S., Buchanan, A. \& Connolly, A. 2001: One Hundred Islands: The Flora of the Outer Furneaux. DPIWE, Printing Authority of Tasmania, Hobart: 361 pp.

Harris, S. \& McKenny, H. 1999: Preservation Island, Furneaux Group: two hundred years of vegetation change. Papers and Proceedings of the Royal Society of Tasmania 133(1): 85-101.

Harris, S. \& Reid, A. (eds) 2011: Inner (West) Sister Island Scientific Expedition 2010. Hamish Saunders Memorial Trust, New Zealand and Resource Management and Conservation Division, DPIPWE, Hobart, Nature Conservation Report Series 11/2: $140 \mathrm{pp}$

Harris, S. \& Lazarus, E. 2006: Ecological observations on a remote montane occurrence of Bedfordia arborescens (Asteraceae), Cape Barren Island, Tasmania. Papers and Proceedings of the Royal Society of Tasmania 140: 35-48.

Harris, S., Ziegler, K. \& Dell, M. 2015: The vegetation and flora of Strzelecki National Park, Flinders Island, Tasmania. Cunninghamia 15: 163-184.

Helmstedt, K.J., Shaw, J.D., Bode, M., Terauds, A., Springer, K., Robinson, S.A. \& Possingham, H. 2016: Prioritizing eradication actions on islands: it's not all or nothing. Journal of Applied Ecology 53: 733-741.

Jennings, J.N. 1959: The coastal geomorphology of King Island, Bass Strait, in relation to change in the relative level of land and sea. Records of the Queen Victoria Museum, Launceston 11: 1-37.

Kirkpatrick, J.B. \& Harwood, C.E. 1983: Plant communities of Tasmanian wetlands. Australian Journal of Botany 31: 437-451.

Kirkwood, J. \& O'Connor, J. (eds) 2010: The state of Australia's birds 2010: islands and birds. Supplement to Wingspan 20(4): $52 \mathrm{pp}$

Kirkwood, R., Pemberton, D., Gales, R., Hoskins, A.J., Mitchell, T., Shaughnessy, P.D. \& Arnould, J.P.Y. 2010: Continued population recovery by Australian fur seals. Marine and Freshwater Research 61: 695-701.

Lohr, C.A., Baker, C.M., Bode, M. \& Pressey, R.L. 2018: What's next on the list? Prioritising management actions on Australia's islands. In Moro, D., Ball, D. \& Bryant, S.L. (eds): Australian Island Arks: Conservation, Management and Opportunities. CSIRO Publishing, Clayton South, Victoria: 71-84

McWethy, D.B., Haberle, S.G., Hopf, F. \& Bowman, D.M.J.S. 2017: Aboriginal impacts on fire and vegetation on a Tasmanian island. Journal of Biogeography 44(6): 1319-1330.

Mallick, S.A. \& Driessen, M.M. 2009: Review, risk assessment and management of introduced animals in the Tasmanian Wilderness World Heritage Area. Nature Conservation Report 10/01. Department of Primary Industries, Parks, Water and Environment, Tasmania: $66 \mathrm{pp}$.

Mallon, K. 2007: Climate change impacts on marine and coastal birds. Waves 13: 10

Mesibov, R. 2019: Times have changed for field work in Tasmania. The Tasmanian Naturalist 141: 137-143.

Moro, D., Ball, D. \& Bryant, S.L. (eds) 2018: Australian Island Arks: Conservation, management and opportunities. CSIRO Publishing, Clayton South, Victoria: 264 pp.

National Parks \& Wildlife Service 1972: Report for the year ended 1972. Report presented to both Houses of Parliament pursuant to section 6 of the National Parks and Wildlife Act 1970. Government Printer, Hobart: 114 pp.

NCHD Natural \& Cultural Heritage Division 2014: Flinders Island: Natural Values Survey 2012. Hamish Saunders Memorial Trust, New Zealand and Natural and Cultural
Heritage Division, DPIPWE, Hobart. Nature Conservation Report Series 14/1: 134 pp.

Parsons, K.E. 2011: Nowhere Else on Earth: Tasmania's Marine Natural Values. Report for Environment Tasmania. Aquenal, Tasmania: $102 \mathrm{pp}$.

Pfennigwerth, S. 2008: Feral Animals of Tasmania. WorldWide Fund for Nature Australia, Threatened Species Network, Hobart: 62 pp.

Polis, G.A. \& Hurd, S.D. 1996: Linking marine and terrestrial food webs: allochthonous input from the ocean supports high secondary productivity on small islands and coastal land communities. American Naturalist 147(3): 396-423.

Prahalad, V., Kirkpatrick, J. \& Mount, R. 2012: Tasmanian coastal salt marsh community transitions associated with climate change and relative sea level rise 1975-2009. Australian Journal of Botany 59: 741-748.

Prahalad, V. \& Pearson, J. 2013: Southern Tasmanian Saltmarsh Futures: A Preliminary Strategic Assessment. NRM South, Hobart, Tasmania: 73 pp.

PWS 1998: Maria Island National Park and Ile des Phoques Nature Reserve Management Plan 1998. Parks and Wildlife Service, Tasmania: $120 \mathrm{pp}$.

PWS 2006: Macquarie Island Nature Reserve and World Heritage Area Management Plan. Parks and Wildlife Service. Department of Tourism, Arts and the Environment, Hobart: 207 pp.

Robinson, S. \& Dick, W. 2020: Black rats eradicated from Big Green Island in Bass Strait, Tasmania. Papers and Proceedings of the Royal Society of Tasmania 154: 37-46.

Robinson, S. \& Gadd, L. 2020: Unviable feral cat population results in eradication success on Wedge Island, Tasmania. Papers and Proceedings Royal Society 154: 47-50.

Robinson, S., Gadd, L., Johnston, M. \& Pauza, M. 2015: Longterm protection of important seabird breeding colonies on Tasman Island through eradication of cats. New Zealand Journal of Ecology 39(2): 316-322.

Rounsevell, D. 1989: Managing offshore island reserves for nature conservation in Tasmania. In Burbidge, A. (ed): Australian and New Zealand islands: nature conservation values and management. Department of Conservation and Land Management, Perth, Western Australia: 157-161.

RPDC 2006: State of the Environment Tasmania. Resource Planning and Development Commission last modified 14 December 2006 (http//www.rpdc.tas.gov. au/RPDCr).

Secretariat of the Convention on Biological Diversity 2014: Island Biodiversity - Island Bright Spots in Conservation \& Sustainability. Secretariat of the Convention on Biological Diversity, Montreal, Canada: 92 pp. (www.unenvironment. $\mathrm{org} /$ resources/report/island-biodiversity-island-bright-spotsconservation-sustainability).

Selkirk, P.M., Seppelt, R.D. \& Selkirk, D.R. (1990) Subantarctic Macquarie Island: environment and biology. Cambridge University Press, Cambridge: 285 pp.

Seymour, D.B., Green, G.R. \& Calver, C.R. 2007: The geology and mineral deposits of Tasmania: a summary. Geological Survey Bulletin 72. Mineral Resources Tasmania, Department of Infrastructure, Energy and Resources, Tasmania: $32 \mathrm{pp}$.

Sharples, C. 2006: Indicative mapping of Tasmanian coastal vulnerability to climate change and sea-level rise: Explanatory report (second edn). Consultant Report to Department of Primary Industries \& Water, Hobart, Tasmania: $173 \mathrm{pp}$.

Springer, K. 2018: Island pest management. In Moro, D., Ball, D. \& Bryant, S.L. (eds): Australian Island Arks: Conservation, Management and Opportunities. CSIRO Publishing, Clayton South, Victoria: 85-98.

Statham, M. \& Middleton, M. 1987: Feral pigs on Flinders Island. Papers and Proceedings of the Royal Society of Tasmania 121: $121-124$.

Tasmanian Planning Commission 2009: State of the Environment Report: Tasmania 2009. Tasmanian Planning Commission, Tasmania: 20 pp. (www.planning.tas.gov.au/_data/ 
assets/pdf_file/0006/332736/State_of_the_Environment_ overview_2009.pdf)

TASMAP 2006: Islands of Tasmania Map Scale 1:600,000 TASMAP Production. State Government of Tasmania, Hobart, Tasmania.

Terauds, A. 2005: Introduced animals on Tasmanian Islands. Biodiversity Conservation Branch, Department of Primary Industries, Water and Environment (DPIWE), Hobart, Tasmania: 19 pp.

Terauds, A. \& Stewart, F. 2009: Subantarctic Wilderness: Macquarie Island. Allen \& Unwin, NSW: 176 pp.

Threatened Species Unit 2001: Pedra Branca Skink Recovery Plan. Department of Primary Industries, Water and Environment (DPIWE), Hobart: $22 \mathrm{pp}$.

TLC 2019: Newsletter No 60 Tasmanian Land Conservancy (https:// tasland.org.au/content/uploads/2019/12/NL60_TLCWEB.pdf).

TPC 2009: Natural values chapter and introduced species on offshore islands indicator. State of the Environment Report: Tasmania 2009. Tasmanian Planning Commission, Tasmania: 20 pp. (https://epa.tas.gov.au/epa/air/legislativecontext-air-quality-in-tasmania/state-of-the-environmentreports)

TSS 2012: King Island Biodiversity Management Plan. Threatened Species Section, Department of Primary Industries, Parks, Water and Environment (DPIPWE), Hobart: 144 pp.

Webb, M.H., Holdsworth, M., Stojanovic, D., Terauds, A., Bell P. \& Heinsohn, R. 2016: Immediate action required to prevent another Australian avian extinction: the King Island Scrubtit. Emu 116: 223-229.
Whinam, J. \& Shaw, J.D. 2018: Australia's World Heritage islands. In Moro, D., Ball, D. \& Bryant, S.L. (eds): Australian Island Arks: Conservation, Management and Opportunities. CSIRO Publishing, Clayton South, Victoria: 147-164.

Wildlife Management Branch 2010: Game Tracks Issue 15 Department of Primary Industries, Parks, Water and Environment (DPIPWE), Hobart: $60 \mathrm{pp}$.

Williamson, P.E. 1988: Origin, structural and tectonic history of the Macquarie Island region. Papers and Proceedings of the Royal Society of Tasmania 122(1): 27-43.

Wise, P., Lee, D., Peck, S., Clarke, J., Thalmann, S., Hockley, J., Schaap, D. \& Pemberton, D. 2016: The conservation introduction of Tasmanian devils to Maria Island National Park: A response to Devil Facial Tumour Disease (DFTD). In Soorae, P.S. (ed.): Global Re-introduction Perspectives: 2016. Case studies From Around the Globe. Gland, Switzerland: $166-171$.

Woehler, E.J. \& Ruoppolo, V. 2010: Shorebirds and seabirds of Flinders and King Islands. In Kirkwood, J. \& J. O'Connor, J. (eds): The state of Australia's birds 2010: islands and birds. Supplement to Wingspan 20(4): 10-11.

Woinarski, J.C.Z., Burbidge, A.A. \& Reside, A.E. 2018 Enhancing island conservation outcomes: the policy and legal context, need, and options. In Moro, D., Ball, D. \& Bryant, S.L. (eds): Australian Island Arks: Conservation Management and Opportunities. CSIRO Publishing, Clayton South, Victoria: 45-60.

(Accepted 30 October 2020)

\section{APPENDIX 1 - Threatened Land-based fauna recorded on Tasmania's offshore islands.}

Species identified from (https://dpipwe.tas.gov.au/conservation/threatened-species-and-communities/lists-of-threatened-species/full-list-ofthreatened-species; last updated 16 July 2020). Status in Tasmania TAS on the Threatened Species Protection Act 1995 and Commonwealth $\mathrm{CW}$ status refers to listings under the Environment Protection and Biodiversity Conservation Act 1999. Status code: CR critically endangered, e, EN endangered, $x$, EX extinct, $v$, VU vulnerable, $r$ rare. Accuracy of distribution records on the Natural Values Atlas (Department of Primary Industries, Water and Environment, accessed 20 Oct 2020), is variable for many species (https://dpipwe.tas.gov.au/conservation/ development-planning-conservation-assessment/planning-tools/natural-values-atlas). See notes below for more information.

\begin{tabular}{|c|c|c|c|c|c|}
\hline Vertebrate species $^{1}$ & Common name & Group & $\begin{array}{l}\text { Status } \\
\text { TAS }\end{array}$ & $\begin{array}{c}\text { Status } \\
\text { CW }\end{array}$ & Key island or group ${ }^{2}$ \\
\hline Arctocephalus forsteri & $\begin{array}{l}\text { Long-nosed (NZ) Fur } \\
\text { Seal }\end{array}$ & MAMMALS & $\mathrm{r}$ & - & $\begin{array}{l}\text { Macquarie, Maatsuyker, Flat } \\
\text { Witch, Tasman, Taillefer } \\
\text { Rocks, Ile des Phoques, Cape } \\
\text { Raoul, Cape Pillar, Wendar } \\
\text { and others in Bass Strait }\end{array}$ \\
\hline Arctocephalus tropicalis & Subantarctic Fur Seal & MAMMALS & e & $\mathrm{EN}$ & $\begin{array}{l}\text { Macquarie and occasionally } \\
\text { elsewhere }\end{array}$ \\
\hline Dasyurus maculatus & Spotted-tailed Quoll & MAMMALS & $\mathrm{r}$ & VU & King (now extinct) $)^{3}$ \\
\hline Dasyurus viverrinus & Eastern Quoll & MAMMALS & - & $\mathrm{EN}$ & Bruny ${ }^{4}$ \\
\hline Mirounga leonina & Southern Elephant Seal & MAMMALS & e & VU & $\begin{array}{l}\text { Macquarie, Maatsuyker, } \\
\text { Bruny, King, Forsyth and } \\
\text { occasionally elsewhere }\end{array}$ \\
\hline Perameles gunnii gunnii & Eastern-barred Bandicoot & MAMMALS & - & VU & Bruny ${ }^{4}$ \\
\hline Pseudomys novaehollandiae & New Holland Mouse & MAMMALS & $\mathrm{e}$ & VU & Flinders \\
\hline Sarcophilus harrisii & Tasmanian Devil & MAMMALS & $\mathrm{e}$ & EN & Robbins, Maria \\
\hline Acanthiza pusilla archibaldi & Brown Thornbill (King Is) & BIRDS & e & EN & King \\
\hline Acanthornis magna greeniana & Scrubtit (King Island) & BIRDS & $\mathrm{e}$ & CR & King \\
\hline Accipiter novaehollandiae & Grey Goshawk & BIRDS & e & - & Bruny 5 , may be elsewhere \\
\hline Aquila audax fleayi & Wedge-tailed Eagle & BIRDS & $\mathrm{e}$ & EN & Many islands inc Bruny \\
\hline
\end{tabular}


APPENDIX 1 - cont.

\begin{tabular}{|c|c|c|c|c|c|}
\hline Vertebrate species ${ }^{1}$ & Common name & Group & $\begin{array}{l}\text { Status } \\
\text { TAS }\end{array}$ & $\begin{array}{c}\text { Status } \\
\text { CW }\end{array}$ & Key island or group ${ }^{2}$ \\
\hline Botaurus poiciloptilus & Australasian Bittern & BIRDS & - & $\mathrm{EN}$ & King, Flinders, Bruny 5 \\
\hline Calidris ferruginea & Curlew Sandpiper & BIRDS & - & $\mathrm{CR}$ & $\begin{array}{l}\text { King, Perkins, Furneaux } \\
\text { Group, occasionally elsewhere }\end{array}$ \\
\hline Ceyx azureus diemenensis & $\begin{array}{l}\text { Tasmanian Azure } \\
\text { Kingfisher }\end{array}$ & BIRDS & $\mathrm{e}$ & EN & $\begin{array}{l}\text { Flinders, King, Bruny, } \\
\text { occasionally elsewhere }\end{array}$ \\
\hline $\begin{array}{l}\text { Cyanoramphus novaezelandiae } \\
\text { erythrotis }\end{array}$ & Macquarie Island Parakeet & BIRDS & $\mathrm{x}$ & EX & Macquarie $^{6}$ \\
\hline Diomedea exulans & Wandering Albatross & BIRDS & e & VU & Macquarie $^{6}$ \\
\hline Dromaius minor & King Island Emu & BIRDS & $\mathrm{x}$ & EX & King \\
\hline $\begin{array}{l}\text { Gallirallus philippensis } \\
\text { macquariensis }\end{array}$ & Macquarie Island Rail & BIRDS & $\mathrm{x}$ & EX & Macquarie $^{6}$ \\
\hline Haliaeetus leucogaster & White-bellied Sea-Eagle & BIRDS & $\mathrm{v}$ & - & $\begin{array}{l}\text { Many islands including King, } \\
\text { Flinders, Maria, Bruny and } \\
\text { Maatsuyker Group }\end{array}$ \\
\hline Halobaena caerulea & Blue Petrel & BIRDS & $\mathrm{v}$ & VU & Macquarie $^{6}$ \\
\hline Lathamus discolor & Swift Parrot & BIRDS & e & $\mathrm{CR}$ & $\begin{array}{l}\text { Maria, Bruny, Flinders, } \\
\text { Partridge, possibly elsewhere }\end{array}$ \\
\hline Leucocarbo atriceps purpurascens & Macquarie Island Shag & BIRDS & $\mathrm{v}$ & VU & Macquarie $^{6}$ \\
\hline Macronectes giganteus & Southern Giant Petrel & BIRDS & $\mathrm{v}$ & $\mathrm{EN}$ & $\begin{array}{l}\text { Macquarie }{ }^{6} \text {, occasionally } \\
\text { elsewhere }\end{array}$ \\
\hline Macronectes halli & Northern Giant Petrel & BIRDS & $\mathrm{r}$ & VU & $\begin{array}{l}\text { Macquarie }{ }^{6} \text {, occasionally } \\
\text { elsewhere }\end{array}$ \\
\hline Neophema chrysogaster & Orange-bellied Parrot & BIRDS & e & CR & $\begin{array}{l}\text { King, possibly others in } \\
\text { Boullanger Bay, Bruny } \\
\text { (historic) }\end{array}$ \\
\hline Numenius madagascariensis & Eastern Curlew & BIRDS & e & CR & $\begin{array}{l}\text { Flinders, King, Bruny, Robbins, } \\
\text { Kangaroo, recorded elsewhere }\end{array}$ \\
\hline Oceanites oceanicus & Wilson's Storm Petrel & BIRDS & $\mathrm{r}$ & - & Macquarie $^{6}$ \\
\hline Pachyptila turtur subantarctica & $\begin{array}{l}\text { Fairy Prion southern sub- } \\
\text { species }\end{array}$ & BIRDS & e & VU & Macquarie $^{6}$ \\
\hline Pardalotus quadragintus & Forty-spotted Pardalote & BIRDS & e & EN & $\begin{array}{l}\text { King }(\text { extinct })^{3} \text {, Flinders, Maria, } \\
\text { Bruny, Partridge }\end{array}$ \\
\hline Phoebetria fusca & Sooty Albatross & BIRDS & $\mathrm{r}$ & VU & Macquarie $^{6}$ \\
\hline Phoebetria palpebrata & Light-mantled Albatross & BIRDS & $\mathrm{v}$ & - & Macquarie $^{6}$ \\
\hline Platycercus caledonicus brownii & King Island Green Rosella & BIRDS & $\mathrm{v}$ & VU & King \\
\hline Procellaria cinerea & Grey Petrel & BIRDS & e & - & Macquarie $^{6}$ \\
\hline Pterodroma lessonii & White-headed Petrel & BIRDS & $\mathrm{v}$ & - & Macquarie $^{6}$ \\
\hline Pterodroma mollis & Soft-plumaged Petrel & BIRDS & e & VU & Macquarie ${ }^{6}$, Maatsuyker \\
\hline Sterna striata & White-fronted Tern & BIRDS & $\mathrm{v}$ & - & $\begin{array}{l}\text { Mainly islands in the Furneaux } \\
\text { including truwana-Cape Barren, } \\
\text { also Albatross and elsewhere }\end{array}$ \\
\hline Sterna vittata bethunei & Antarctic Tern & BIRDS & e & EN & Macquarie $^{6}$ \\
\hline Sternula albifrons sinensis & Little Tern & BIRDS & e & - & $\begin{array}{l}\text { King, Flinders, islands in Bass } \\
\text { Strait and Boullanger Bay }\end{array}$ \\
\hline Sternula nereis nereis & Fairy Tern & BIRDS & $\mathrm{v}$ & VU & $\begin{array}{l}\text { King, Flinders, islands in Bass } \\
\text { Strait and Boullanger Bay and } \\
\text { elsewhere }\end{array}$ \\
\hline Strepera fuliginosa colei & Black Currawong (King Is) & BIRDS & - & VU & King \\
\hline Thalassarche cauta & Shy Albatross & BIRDS & $\mathrm{v}$ & $\mathrm{EN}$ & $\begin{array}{l}\text { Albatross, Pedra Branca, } \\
\text { Mewstone, occasionally } \\
\text { elsewhere }\end{array}$ \\
\hline
\end{tabular}


APPENDIX 1 - cont.

\begin{tabular}{|c|c|c|c|c|c|}
\hline Vertebrate species ${ }^{1}$ & Common name & Group & $\begin{array}{l}\text { Status } \\
\text { TAS }\end{array}$ & $\begin{array}{c}\text { Status } \\
\text { CW }\end{array}$ & Key island or group ${ }^{2}$ \\
\hline Thalassarche chrysostoma & Grey-headed Albatross & BIRDS & $\mathrm{e}$ & EN & $\begin{array}{l}\text { Macquarie }{ }^{6} \text {, occasionally } \\
\text { elsewhere }\end{array}$ \\
\hline Thalassarche melanophris & Black-browed Albatross & BIRDS & e & VU & $\begin{array}{l}\text { Macquarie }{ }^{6} \text {, occasionally } \\
\text { elsewhere }\end{array}$ \\
\hline Thinornis cucullatus cucullatus & Hooded Plover (Eastern) & BIRDS & - & VU & $\begin{array}{l}\text { Many islands including King, } \\
\text { Flinders, Bruny, Maria and in } \\
\text { Bass Strait }\end{array}$ \\
\hline $\begin{array}{l}\text { Tyto novaehollandiae } \\
\text { castanops }\end{array}$ & Masked Owl & BIRDS & $\mathrm{e}$ & VU & $\begin{array}{l}\text { Bruny } 5 \text {, Maria, Trefoil, Betsey, } \\
\text { occasionally elsewhere }\end{array}$ \\
\hline Litoria raniformis & Green and Gold Frog & AMPHIBIANS & $\mathrm{v}$ & VU & King, Flinders, Maria \\
\hline Limnodynastes peroni & Striped Marsh Frog & AMPHIBIANS & $\mathrm{e}$ & - & King \\
\hline Carinascincus palfreymani & Pedra Branca Skink & REPTILES & $\mathrm{e}$ & VU & Pedra Branca \\
\hline Pseudemoia rawlinsoni & Glossy Grass Skink & REPTILES & $\mathrm{r}$ & - & truwana-Cape Barren, Picnic? \\
\hline Pseudemoia pagenstecheri & Tussock Skink & REPTILES & $\mathrm{v}$ & - & truwana-Cape Barren \\
\hline Galaxiella pusilla & Dwarf Galaxias & FISH & $\mathrm{v}$ & VU & Flinders \\
\hline Invertebrate species & Common name & Order & $\begin{array}{l}\text { Status } \\
\text { TAS }\end{array}$ & $\begin{array}{c}\text { Status } \\
\text { CW }\end{array}$ & Island or group \\
\hline Austrorhytida lamproides & Keeled Snail & $\begin{array}{l}\text { SIGMURE- } \\
\text { THRA }\end{array}$ & $\mathrm{r}$ & - & Three Hummock \\
\hline Cavernotettix craggiensis & $\begin{array}{l}\text { Craggy Island Cave } \\
\text { Cricket }\end{array}$ & $\begin{array}{l}\text { ORTHOP- } \\
\text { TERA }\end{array}$ & $\mathrm{r}$ & - & Craggy (north west of Flinders) \\
\hline Chloritobadistes victoriae & Southern Hairy Red Snail & $\begin{array}{l}\text { EUPUL- } \\
\text { MONATA }\end{array}$ & $\mathrm{v}$ & - & King \\
\hline Dasyurotaenia robusta & $\begin{array}{l}\text { Tapeworm (Tasmanian } \\
\text { Devil) }\end{array}$ & $\begin{array}{l}\text { CYCLO- } \\
\text { PHYLLIDEAE }\end{array}$ & $\mathrm{r}$ & - & Robbins, Maria \\
\hline Echinodillo cavaticus & Flinders Island Cave Slater & ISOPODA & $\mathrm{r}$ & - & Flinders \\
\hline Engaeus martigener & $\begin{array}{l}\text { Furneaux Burrowing } \\
\text { Crayfish }\end{array}$ & DECAPODA & $\mathrm{v}$ & $\mathrm{EN}$ & Flinders, truwana-Cape Barren \\
\hline Lissotes latidens & Broad-toothed Stag Beetle & $\begin{array}{l}\text { COLEOP- } \\
\text { TERA }\end{array}$ & e & EN & Maria \\
\hline Lissotes menalcas & Mt. Mangana Stag Beetle & COLEOPTERA & r & - & Bruny \\
\hline Parvotettix rangaensis & Cave Cricket & ORTHOPTERA & $\mathrm{r}$ & - & truwana-Cape Barren \\
\hline Parvotettix whinrayi & Whinray's Cave Cricket & ORTHOPTERA & r & - & Flinders \\
\hline Theclinesthes serpentata & Chequered Blue & LEPIDOPTERA & $\mathrm{r}$ & - & Flinders, Diamond \\
\hline
\end{tabular}

1 Table does not include Grey-headed Flying-fox Pteropus poliocephalus, or Great Knot Calidris tenuirostris (listed on EPBC but not on https://dpipwe.tas.gov.au/conservation/threatened-species-and-communities/lists-of-threatened-species/full-list-of-threatened-species) or White-throated Needletail Hirundapus caudacutus as mainly arboreal

2 Only main islands mentioned and may be recorded on islands elsewhere.

3 Additional reference for Spotted-tailed Quoll and Forty-spotted Pardalote: Donaghey, R. (ed.) 2003: The fauna of King Island: A guide to identification and conservation management. King Island Natural Resource Management Group Inc. King Island: 152 pp.

${ }^{4}$ Additional reference for Eastern Quoll and Eastern-barred Bandicoot: Driessen, M.M., Carlyon, K., Gales, R., Mooney, N., Pauza, M., Thurstans, S., Visoiu, M. \& Wise, P. 2011: Terrestrial mammals of a sheep-grazing property on Bruny Island, Tasmania. Papers and Proceedings of the Royal Society of Tasmania 145: 51-64.

5 Birds on Bruny Island supported by the checklist: https://www.brunybirdfestival.org.au/images/downloads/Bird_Festival_2018_-Checklist_of_bird_species_found_on_Bruny_Island.pdf

${ }^{6}$ Macquarie Island species source https://avibase.bsc-eoc.org/checklist.jsp?region=AUmi\&list=howardmoore (accessed 1 October 2020). 
APPENDIX 2 - Threatened flora species recorded on Tasmania's offshore islands. ${ }^{1}$

\begin{tabular}{|c|c|c|c|c|c|}
\hline Species name 3 & Common name & Family ${ }^{3}$ & $\begin{array}{l}\text { Status }^{2} \\
\text { TAS }\end{array}$ & $\begin{array}{l}\text { Status }^{2} \\
\text { CW }\end{array}$ & Island or group \\
\hline Acacia ulicifolia & Juniper Wattle & Fabaceae & rare & & $\begin{array}{l}\text { Flinders Island; Three Hummock } \\
\text { Island; Bruny Island }\end{array}$ \\
\hline Acrotriche cordata & Coast Groundberry & Ericaceae & vulnerable & & Prime Seal Island; Flinders Island \\
\hline Allocasuarina crassa & Cape Pillar Sheoak & Casuarinaceae & rare & & Tasman Island \\
\hline Allocasuarina duncanii & Conical Sheoak & Casuarinaceae & rare & & Bruny Island \\
\hline Aphelia gracilis & Slender Fanwort & Centrolepidaceae & rare & & Flinders Island \\
\hline Asperula minima & Mossy Woodruff & Rubiaceae & rare & & $\begin{array}{l}\text { Inner Sister Island; Vansittart Island; } \\
\text { Inner Sister Island; Flinders Island }\end{array}$ \\
\hline $\begin{array}{l}\text { Asperula scoparia var. } \\
\text { scoparia }\end{array}$ & Prickly Woodruff & Rubiaceae & rare & & Bruny Island \\
\hline Asperula subsimplex & Water Woodruff & Rubiaceae & rare & & Flinders Island \\
\hline Atriplex suberecta & Sprawling Saltbush & Amaranthaceae & vulnerable & & $\begin{array}{l}\text { Little Chalky Island; Wybalenna } \\
\text { Island; Boxen Island; Badger Island; } \\
\text { Beagle Island; Little Badger Island; } \\
\text { Outer Green Island }\end{array}$ \\
\hline $\begin{array}{l}\text { Australina pusilla } \\
\text { subsp. muelleri }\end{array}$ & Shade Nettle & Urticaceae & rare & & King Island \\
\hline $\begin{array}{l}\text { Austrodanthonia } \\
\text { remota }\end{array}$ & $\begin{array}{l}\text { Remote } \\
\text { Wallabygrass }\end{array}$ & Poaceae & rare & & Hibbs Pyramid \\
\hline $\begin{array}{l}\text { Austrostipa } \\
\text { bigeniculata }\end{array}$ & $\begin{array}{l}\text { Doublejointed } \\
\text { Speargrass }\end{array}$ & Poaceae & rare & & Anderson Islands \\
\hline Austrostipa blackii & Crested Speargrass & Poaceae & rare & & Bruny Island \\
\hline Azorella macquariensis & $\begin{array}{l}\text { Macquarie } \\
\text { Cushions }\end{array}$ & Apiaceae & endangered & $\begin{array}{l}\text { Critically } \\
\text { endangered }\end{array}$ & Macquarie Island \\
\hline Banksia integrifolia & Coast Banksia & Proteaceae & extinct & & Long Island; Hogan Group \\
\hline Banksia serrata & Saw Banksia & Proteaceae & rare & & Flinders Island \\
\hline Baumea gunnii & Slender Twigsedge & Cyperaceae & rare & & Schouten Island, Flinders Island \\
\hline Bedfordia arborescens & Tree Blanketleaf & Asteraceae & vulnerable & & Cape Barren Island \\
\hline $\begin{array}{l}\text { Bolboschoenus } \\
\text { caldwellii }\end{array}$ & Sea Clubsedge & Cyperaceae & rare & & King Island \\
\hline $\begin{array}{l}\text { Bolboschoenus } \\
\text { medianus }\end{array}$ & Marsh Clubsedge & Cyperaceae & rare & & King Island \\
\hline Brachyloma depressum & Spreading Heath & Ericaceae & rare & & $\begin{array}{l}\text { Flinders Island; Clarke Island; } \\
\text { Schouten Island }\end{array}$ \\
\hline Brachyscome perpusilla & Tiny Daisy & Asteraceae & rare & & Flinders Island \\
\hline Caladenia aurantiaca & Orangetip Fingers & Orchidaceae & endangered & & Deal Island \\
\hline Caladenia australis & $\begin{array}{l}\text { Southern Spider- } \\
\text { Orchid }\end{array}$ & Orchidaceae & endangered & & Flinders Island \\
\hline Caladenia brachyscapa & $\begin{array}{l}\text { Short Spider- } \\
\text { Orchid }\end{array}$ & Orchidaceae & endangered & Extinct & Clarke Island; Cape Barren Island \\
\hline Caladenia cardiochila & $\begin{array}{l}\text { Heartlip Spider- } \\
\text { Orchid }\end{array}$ & Orchidaceae & extinct & & Flinders Island \\
\hline Caladenia caudata & $\begin{array}{l}\text { Tailed Spider- } \\
\text { Orchid }\end{array}$ & Orchidaceae & vulnerable & Vulnerable & $\begin{array}{l}\text { Bruny Island; Schouten Island; Clarke } \\
\text { Island; Cape Barren Island; Flinders } \\
\text { Island }\end{array}$ \\
\hline $\begin{array}{l}\text { Caladenia filamentosa } \\
\text { var. filamentosa }\end{array}$ & Daddy Longlegs & Orchidaceae & rare & & $\begin{array}{l}\text { Bruny Island; Schouten Island; } \\
\text { Flinders Island }\end{array}$ \\
\hline
\end{tabular}


100 Sally L. Bryant and Stephen Harris

APPENDIX 2 - cont.

\begin{tabular}{|c|c|c|c|c|c|}
\hline Species name 3 & Common name & Family 3 & $\begin{array}{l}\text { Status }^{2} \\
\text { TAS }\end{array}$ & $\begin{array}{l}\text { Status }^{2} \\
\text { CW }\end{array}$ & Island or group \\
\hline Caladenia prolata & White Fingers & Orchidaceae & endangered & & Deal Island; Flinders Island \\
\hline Caladenia pusilla & Tiny Fingers & Orchidaceae & rare & & $\begin{array}{l}\text { King Island; Three Hummock Island; } \\
\text { Cape Barren Island; Flinders Island; } \\
\text { Deal Island }\end{array}$ \\
\hline $\begin{array}{l}\text { Calandrinia } \\
\text { granulifera }\end{array}$ & Pygmy Purslane & Portulacaceae & rare & & Cape Barren Island; Flinders Island \\
\hline Callitriche sonderi & $\begin{array}{l}\text { Matted } \\
\text { Waterstarwort }\end{array}$ & Plantaginaceae & rare & & King Island \\
\hline Calochilus campestris & $\begin{array}{l}\text { Copper Beard- } \\
\text { Orchid }\end{array}$ & Orchidaceae & endangered & & Cape Barren Island; Clarke Island \\
\hline Calystegia marginata & Forest Bindweed & Convolvulaceae & endangered & & Cape Barren Island \\
\hline Calystegia soldanella & Sea Bindweed & Convolvulaceae & rare & & $\begin{array}{l}\text { Bruny Island; King Island; East } \\
\text { Kangaroo Island; Anderson Islands }\end{array}$ \\
\hline Carex gunniana & Mountain Sedge & Cyperaceae & rare & & Bruny Island \\
\hline Caustis pentandra & Thick Twistsedge & Cyperaceae & rare & & Schouten Island \\
\hline $\begin{array}{l}\text { Centipeda } \\
\text { cunninghamii }\end{array}$ & Erect Sneezeweed & Asteraceae & rare & & King Island \\
\hline $\begin{array}{l}\text { Centrolepis strigosa } \\
\text { subsp. pulvinata }\end{array}$ & Bassian Bristlewort & Centrolepidaceae & rare & & $\begin{array}{l}\text { Cape Barren Island, Hogan Island; } \\
\text { Deal Island }\end{array}$ \\
\hline Chenopodium erosum & Papery Goosefoot & Amaranthaceae & extinct & & Kent Group \\
\hline $\begin{array}{l}\text { Chiloglottis } \\
\text { trapeziformis }\end{array}$ & $\begin{array}{l}\text { Broadlip Bird- } \\
\text { Orchid }\end{array}$ & Orchidaceae & endangered & & Flinders Island; Great Dog Island \\
\hline Chiloglottis valida & Large Bird-Orchid & Orchidaceae & $\begin{array}{l}\text { listing as } \\
\text { endangered } \\
\text { pending } \\
\text { (unofficial) }\end{array}$ & & King Island \\
\hline $\begin{array}{l}\text { Chrysocephalum } \\
\text { baxteri }\end{array}$ & Fringed Everlasting & Asteraceae & rare & & $\begin{array}{l}\text { Clarke Island; Cape Barren Island; } \\
\text { Flinders Island }\end{array}$ \\
\hline $\begin{array}{l}\text { Comesperma } \\
\text { defoliatum }\end{array}$ & Leafless Milkwort & Polygalaceae & rare & & Cape Barren Island, King Island \\
\hline Conospermum hookeri & $\begin{array}{l}\text { Tasmanian } \\
\text { Smokebush }\end{array}$ & Proteaceae & vulnerable & Vulnerable & $\begin{array}{l}\text { Bruny Island; Cape Barren Island; } \\
\text { Schouten Island }\end{array}$ \\
\hline Corybas dienemus & $\begin{array}{l}\text { Windswept Helmet- } \\
\text { Orchid }\end{array}$ & Orchidaceae & vulnerable & $\begin{array}{l}\text { Critically } \\
\text { endangered }\end{array}$ & $\begin{array}{l}\text { Macquarie Island; Flinders Island; } \\
\text { King Island }\end{array}$ \\
\hline Corybas fordhamii & $\begin{array}{l}\text { Swamp Pelican- } \\
\text { Orchid }\end{array}$ & Orchidaceae & endangered & & Flinders Island \\
\hline Corybas sulcatus & $\begin{array}{l}\text { Grooved Helmet- } \\
\text { Orchid }\end{array}$ & Orchidaceae & endangered & $\begin{array}{l}\text { Critically } \\
\text { endangered }\end{array}$ & Macquarie Island \\
\hline $\begin{array}{l}\text { Cotula vulgaris var. } \\
\text { australasica }\end{array}$ & Slender Buttons & Asteraceae & rare & & $\begin{array}{l}\text { King Island; Three Hummock Island; } \\
\text { Cape Barren Island; Passage Island; } \\
\text { Inner Sister Island; Flinders Island; } \\
\text { Hogan Island; Deal Island }\end{array}$ \\
\hline Crassula moschata & Musky Stonecrop & Crassulaceae & rare & & $\begin{array}{l}\text { Macquarie Island; King Island; Black } \\
\text { Pyramid; Albatross Island; Trefoil } \\
\text { Island; Vansittart Island; Curtis Island; } \\
\text { Bruny Island; Gull Reef Port Davey }\end{array}$ \\
\hline Cryptandra exilis & Slender Pearlflower & Rhamnaceae & $\begin{array}{l}\text { listing as } \\
\text { vulnerable } \\
\text { under con- } \\
\text { sideration } \\
\text { (unofficial) }\end{array}$ & & Schouten Island; Cape Barren Island \\
\hline
\end{tabular}


APPENDIX 2 - cont.

\begin{tabular}{|c|c|c|c|c|c|}
\hline Species name 3 & Common name & Family $^{3}$ & $\begin{array}{l}\text { Status }^{2} \\
\text { TAS }\end{array}$ & $\begin{array}{c}\text { Status }^{2} \\
\text { CW }\end{array}$ & Island or group \\
\hline Cryptostylis leptochila & $\begin{array}{l}\text { Small Tongue- } \\
\text { Orchid }\end{array}$ & Orchidaceae & endangered & & Flinders Island; Cape Barren Island \\
\hline Cuscuta tasmanica & Golden Dodder & Convolvulaceae & rare & & Flinders Island \\
\hline Cyathea cunninghamii & Slender Treefern & Cyatheaceae & endangered & & King Island \\
\hline Cyathea Xmarcescens & Skirted Treefern & Cyatheaceae & endangered & & King Island \\
\hline Cyathodes platystoma & Tall Cheeseberry & Ericaceae & rare & & Bruny Island \\
\hline $\begin{array}{l}\text { Cyphanthera } \\
\text { tasmanica }\end{array}$ & $\begin{array}{l}\text { Tasmanian } \\
\text { Rayflower }\end{array}$ & Solanaceae & rare & & Maria Island; Schouten Island \\
\hline Cyrtostylis robusta & Large Gnat-Orchid & Orchidaceae & rare & & $\begin{array}{l}\text { Flinders Island; West Sister Island; } \\
\text { Prime Seal Island; Hunter Island; King } \\
\text { Island; Deal Island }\end{array}$ \\
\hline Desmodium gunnii & Southern Ticktrefoil & Fabaceae & vulnerable & & Schouten Island \\
\hline Deyeuxia minor & Small Bentgrass & Poaceae & rare & & Bruny Island \\
\hline Diuris palustris & Swamp Doubletail & Orchidaceae & endangered & & Flinders Island \\
\hline Drosera glanduligera & Scarlet Sundew & Droseraceae & rare & & Flinders Island \\
\hline Elaeocarpus reticulatus & Blueberry Ash & Elaeocarpaceae & rare & & Flinders Island; King Island \\
\hline Epacris barbata & Bearded Heath & Ericaceae & endangered & Endangered & Schouten Island \\
\hline $\begin{array}{l}\text { Epacris virgata } \\
\text { (Kettering) }\end{array}$ & Pretty Heath & Ericaceae & $\begin{array}{l}\text { vulnerable } \\
\text { (unofficial) }\end{array}$ & & Bruny Island \\
\hline $\begin{array}{l}\text { Epilobium } \\
\text { pallidiflorum }\end{array}$ & Showy Willowherb & Onagraceae & $\begin{array}{l}\text { rare, } \\
\text { delisting } \\
\text { pending }\end{array}$ & & King Island; Hunter Island \\
\hline $\begin{array}{l}\text { Eucalyptus globulus } \\
\text { subsp. globulus }\end{array}$ & $\begin{array}{l}\text { Gippsland Blue } \\
\text { Gum }\end{array}$ & Myrtaceae & rare & & $\begin{array}{l}\text { Flinders Island; Inner Sister Island; } \\
\text { Rodondo Island }\end{array}$ \\
\hline $\begin{array}{l}\text { Euphrasia collina } \\
\text { subsp. deflexifolia }\end{array}$ & Eastern Eyebright & Orobanchaceae & rare & & Schouten Island \\
\hline Euphrasia fragosa & Shy Eyebright & Orobanchaceae & endangered & $\begin{array}{l}\text { Critically } \\
\text { endangered }\end{array}$ & Bruny Island \\
\hline Eutaxia microphylla & Spiny Bushpea & Fabaceae & rare & & $\begin{array}{l}\text { Prime Seal Island; Flinders Island; } \\
\text { Cape Barren Island }\end{array}$ \\
\hline $\begin{array}{l}\text { Frankenia pauciflora } \\
\text { var. gunnii }\end{array}$ & Southern Seaheath & Frankeniaceae & rare & & $\begin{array}{l}\text { Harcus Island, Short Island; Little } \\
\text { Goose Island; Preservation Island; } \\
\text { Spike Island; Clarke Island; Rum } \\
\text { Island; Cone Island }\end{array}$ \\
\hline Galium antarcticum & $\begin{array}{l}\text { Subantarctic } \\
\text { Bedstraw }\end{array}$ & Rubiaceae & endangered & $\begin{array}{l}\text { Critically } \\
\text { endangered }\end{array}$ & Macquarie Island \\
\hline Geococcus pusillus & Earth Cress & Brassicaceae & rare & & $\begin{array}{l}\text { Mount Chappell Island; Little Chalky } \\
\text { Island; Mile Island; King Island }\end{array}$ \\
\hline $\begin{array}{l}\text { Gompholobium } \\
\text { ecostatum }\end{array}$ & Dwarf Wedgepea & Fabaceae & endangered & & Flinders Island \\
\hline Gratiola pubescens & Hairy Brooklime & Plantaginaceae & rare & & $\begin{array}{l}\text { King Island; Cape Barren Island; } \\
\text { Bruny Island }\end{array}$ \\
\hline Gynatrix pulchella & Fragrant Hempbush & Malvaceae & rare & & $\begin{array}{l}\text { Flinders Island; Cape Barren Island; } \\
\text { Maria Island }\end{array}$ \\
\hline Gyrostemon thesioides & Broom Wheelfruit & Gyrostemonaceae & rare & & $\begin{array}{l}\text { Deal Island; Flinders Island; Cape } \\
\text { Barren Island; Clarke Island }\end{array}$ \\
\hline Hackelia latifolia & $\begin{array}{l}\text { Forest } \\
\text { Houndstongue }\end{array}$ & Boraginaceae & rare & & King Island \\
\hline
\end{tabular}


102 Sally L. Bryant and Stephen Harris

APPENDIX 2 - cont.

\begin{tabular}{|c|c|c|c|c|c|}
\hline Species name 3 & Common name & Family $^{3}$ & $\begin{array}{l}\text { Status }^{2} \\
\text { TAS }\end{array}$ & $\begin{array}{c}\text { Status }^{2} \\
\text { CW }\end{array}$ & Island or group \\
\hline Hakea ulicina & Furze Needlebush & Proteaceae & vulnerable & & $\begin{array}{l}\text { Flinders Island; Cape Barren; Clarke } \\
\text { Island }\end{array}$ \\
\hline Haloragis myriocarpa & Prickly Raspwort & Haloragaceae & rare & & $\begin{array}{l}\text { Flinders Island; Clarke Island; Cape } \\
\text { Barren Island; King Island }\end{array}$ \\
\hline Hedycarya angustifolia & Australian Mulberry & Monimiaceae & rare & & King Island \\
\hline Hibbertia obtusifolia & Grey Guineaflower & Dilleniaceae & extinct & & Clarke Island \\
\hline Hydrocotyle comocarpa & $\begin{array}{l}\text { Fringefruit } \\
\text { Pennywort }\end{array}$ & Araliaceae & rare & & $\begin{array}{l}\text { Flinders Island; Cape Barren; Deal } \\
\text { Island }\end{array}$ \\
\hline Hydrorchis orbicularis & $\begin{array}{l}\text { Swamp Onion- } \\
\text { Orchid }\end{array}$ & Orchidaceae & rare & & $\begin{array}{l}\text { Bruny Island; Clarke Island; Cape } \\
\text { Barren Island; Flinders Island }\end{array}$ \\
\hline Hypolepis distans & $\begin{array}{l}\text { Scrambling } \\
\text { Groundfern }\end{array}$ & Dennstaedtiaceae & endangered & Endangered & King Island \\
\hline Hypolepis muelleri & Harsh Groundfern & Dennstaedtiaceae & rare & & Flinders Island; King Island \\
\hline $\begin{array}{l}\text { Isoetes drummondii } \\
\text { subsp. drummondii }\end{array}$ & Plain Quillwort & Isoetaceae & rare & & Flinders Island \\
\hline Isopogon ceratophyllus & Horny Conebush & Proteaceae & vulnerable & & $\begin{array}{l}\text { Cape Barren Island; Flinders Island; } \\
\text { Clarke Island }\end{array}$ \\
\hline Juncus amabilis & Gentle Rush & Juncaceae & $\begin{array}{l}\text { rare, } \\
\text { delisting } \\
\text { pending }\end{array}$ & & Bruny Island \\
\hline Juncus prismatocarpus & Branching Rush & Juncaceae & rare & & Bruny Island \\
\hline Juncus vaginatus & Clustered Rush & Juncaceae & rare & & Wedge Island \\
\hline $\begin{array}{l}\text { Lachnagrostis } \\
\text { billardierei subsp. } \\
\text { tenuiseta }\end{array}$ & $\begin{array}{l}\text { Small-Awn } \\
\text { Blowngrass }\end{array}$ & Poaceae & rare & & $\begin{array}{l}\text { Flinders Island; Forsyth Island; Passage } \\
\text { Island }\end{array}$ \\
\hline Lachnagrostis robusta & Tall Blowngrass & Poaceae & rare & & $\begin{array}{l}\text { Cape Barren Island; Gull Reef Port } \\
\text { Davey; Celery Top Islands; Maria } \\
\text { Island; Cape Barren Island; Flinders } \\
\text { Island }\end{array}$ \\
\hline Lasiopetalum baueri & Slender Velvetbush & Malvaceae & rare & & Flinders Island \\
\hline Lasiopetalum discolor & Coast Velvetbush & Malvaceae & rare & & Prime Seal Island; Cape Barren Island \\
\hline Lepidium flexicaule & Springy Peppercress & Brassicaceae & rare & & $\begin{array}{l}\text { Bruny Island; Three Hummock; Gull } \\
\text { Reef Port Davey; Black Swan Island; } \\
\text { Muttonbird Island }\end{array}$ \\
\hline Lepidosperma forsythii & Stout Rapiersedge & Cyperaceae & rare & & Schouten Island; Cape Barren Island \\
\hline $\begin{array}{l}\text { Lepidosperma } \\
\text { tortuosum }\end{array}$ & $\begin{array}{l}\text { Twisting } \\
\text { Rapiersedge }\end{array}$ & Cyperaceae & rare & & Clarke Island \\
\hline Lepidosperma viscidum & Sticky Swordsedge & Cyperaceae & rare & & Bruny Island \\
\hline Lepilaena patentifolia & Spreading Watermat & $\begin{array}{l}\text { Potamogeton- } \\
\text { aceae }\end{array}$ & rare & & Flinders Island; King Island \\
\hline Lepilaena preissii & Slender Watermat & $\begin{array}{l}\text { Potamogeton- } \\
\text { aceae }\end{array}$ & rare & & Flinders Island \\
\hline Leucopogon affinis & $\begin{array}{l}\text { Lanceleaf } \\
\text { Beardheath }\end{array}$ & Ericaceae & rare & & $\begin{array}{l}\text { King Island; Three Hummock Island; } \\
\text { Clarke Island; Cape Barren Island; } \\
\text { Flinders Island }\end{array}$ \\
\hline $\begin{array}{l}\text { Leucopogon } \\
\text { esquamatus }\end{array}$ & Swamp Beardheath & Ericaceae & rare & & Flinders Island; Cape Barren Island \\
\hline Levenhookia dubia & Hairy Stylewort & Stylidiaceae & extinct & & Flinders Island \\
\hline
\end{tabular}


APPENDIX 2 - cont.

\begin{tabular}{|c|c|c|c|c|c|}
\hline Species name ${ }^{3}$ & Common name & Family $^{3}$ & $\begin{array}{l}\text { Status }^{2} \\
\text { TAS }\end{array}$ & $\begin{array}{c}\text { Status }^{2} \\
\mathrm{CW}\end{array}$ & Island or group \\
\hline Limonium australe & Yellow Sea-Lavender & Plumbaginaceae & rare & & $\begin{array}{l}\text { Harcus Island, Short Island; Perkins } \\
\text { Island }\end{array}$ \\
\hline Lobelia pratioides & Poison Lobelia & Campanulaceae & vulnerable & & Flinders Island \\
\hline Lotus australis & Australian Trefoil & Fabaceae & rare & & $\begin{array}{l}\text { Flinders Island; Swan Island; } \\
\text { Foster Island; Trefoil Island; Three } \\
\text { Hummock Island }\end{array}$ \\
\hline Microtis atrata & $\begin{array}{l}\text { Yellow Onion- } \\
\text { Orchid }\end{array}$ & Orchidaceae & rare & & $\begin{array}{l}\text { Bruny Island, Cape Barren Island and } \\
\text { Flinders Island }\end{array}$ \\
\hline $\begin{array}{l}\text { Myoporum } \\
\text { parvifolium }\end{array}$ & Creeping Boobialla & Scrophulariaceae & vulnerable & & Flinders Island \\
\hline Myriophyllum muelleri & $\begin{array}{l}\text { Hooded } \\
\text { Watermilfoil }\end{array}$ & Haloragaceae & rare & & $\begin{array}{l}\text { King Island; Long Island; Vansittart } \\
\text { Island; Cape Barren Island, Clarke } \\
\text { Island }\end{array}$ \\
\hline Orthoceras strictum & Horned Orchid & Orchidaceae & rare & & $\begin{array}{l}\text { King Island; Schouten Island; Clarke } \\
\text { Island; Cape Barren Island; Flinders } \\
\text { Island }\end{array}$ \\
\hline Pandorea pandorana & Wonga Vine & Bignoniaceae & rare & & Flinders Island \\
\hline Parietaria debilis & Shade Pellitory & Urticaceae & rare & & $\begin{array}{l}\text { King Island; Three Hummock Island; } \\
\text { Erith Island, Deal Island, Rodondo } \\
\text { Island; West Sister Island; Prime Seal } \\
\text { Island; Great Dog Island; Puncheon } \\
\text { Island; Little Green Island; Passage } \\
\text { Island; Babel Island; Mount Chappell } \\
\text { Island; Swan Island; Bruny Island }\end{array}$ \\
\hline Pellaea calidirupium & Hotrock Fern & Adiantaceae & rare & & Deal Island \\
\hline Persicaria decipiens & $\begin{array}{l}\text { Slender } \\
\text { Waterpepper }\end{array}$ & Polygonaceae & vulnerable & & King Island \\
\hline Phyllangium distylis & Tiny Mitrewort & Loganiaceae & rare & & $\begin{array}{l}\text { Flinders Island; Cape Barren Island; } \\
\text { King Island }\end{array}$ \\
\hline Phyllangium divergens & Wiry Mitrewort & Loganiaceae & vulnerable & & $\begin{array}{l}\text { Bruny Island; Clarke Island; Cape } \\
\text { Barren Island }\end{array}$ \\
\hline $\begin{array}{l}\text { Phylloglossum } \\
\text { drummondii }\end{array}$ & Pygmy Clubmoss & Lycopodiaceae & rare & & $\begin{array}{l}\text { King Island, Cape Barren Island and } \\
\text { Flinders Island }\end{array}$ \\
\hline $\begin{array}{l}\text { Pimelea axiflora subsp. } \\
\text { axiflora }\end{array}$ & Bootlace Bush & Thymelaeaceae & endangered & & King Island \\
\hline Pimelea curviflora & Curved Riceflower & Thymelaeaceae & $\begin{array}{l}\text { parent } \\
\text { species } \\
\text { (unofficial) }\end{array}$ & & $\begin{array}{l}\text { Schouten Island; Flinders Island; } \\
\text { Badger Island }\end{array}$ \\
\hline Pimelea micrantha & $\begin{array}{l}\text { Silky Curved } \\
\text { Riceflower }\end{array}$ & Thymelaeaceae & rare & & Flinders Island \\
\hline $\begin{array}{l}\text { Pneumatopteris } \\
\text { pennigera }\end{array}$ & Lime Fern & Thelypteridaceae & endangered & & King Island \\
\hline Poa cookii & Cooks Tussockgrass & Poaceae & endangered & & Macquarie Island \\
\hline Poa halmaturina & Dune Tussockgrass & Poaceae & rare & & Clarke Island; Flinders Island \\
\hline Podotheca angustifolia & Sticky Longheads & Asteraceae & extinct & & King Island \\
\hline Polystichum vestitum & Prickly Shieldfern & Dryopteridaceae & endangered & & Macquarie Island \\
\hline Pomaderris intermedia & Lemon Dogwood & Rhamnaceae & rare & & $\begin{array}{l}\text { Flinders Island; Cape Barren Island; } \\
\text { Schouten Island }\end{array}$ \\
\hline $\begin{array}{l}\text { Pomaderris oraria } \\
\text { subsp. oraria }\end{array}$ & Bassian Dogwood & Rhamnaceae & rare & & Flinders Island \\
\hline
\end{tabular}


104 Sally L. Bryant and Stephen Harris

APPENDIX 2 - cont.

\begin{tabular}{|c|c|c|c|c|c|}
\hline Species name 3 & Common name & Family $^{3}$ & $\begin{array}{l}\text { Status }^{2} \\
\text { TAS }\end{array}$ & $\begin{array}{c}\text { Status }^{2} \\
\text { CW }\end{array}$ & Island or group \\
\hline $\begin{array}{l}\text { Pomaderris paniculosa } \\
\text { subsp. paralia }\end{array}$ & Shining Dogwood & Rhamnaceae & rare & & $\begin{array}{l}\text { King Island; Erith Island; Hogan } \\
\text { Island, Prime Seal Island; Outer Sister } \\
\text { Island; Swan Island; East Sister Island }\end{array}$ \\
\hline $\begin{array}{l}\text { Prasophyllum } \\
\text { apoxychilum }\end{array}$ & $\begin{array}{l}\text { Tapered Leek- } \\
\text { Orchid }\end{array}$ & Orchidaceae & vulnerable & Endangered & Bruny Island \\
\hline Prasophyllum atratum & $\begin{array}{l}\text { Three Hummock } \\
\text { Leek-Orchid }\end{array}$ & Orchidaceae & endangered & $\begin{array}{l}\text { Critically } \\
\text { Endangered }\end{array}$ & $\begin{array}{l}\text { Three Hummock Island; Hunter } \\
\text { Island }\end{array}$ \\
\hline $\begin{array}{l}\text { Prasophyllum } \\
\text { castaneum }\end{array}$ & $\begin{array}{l}\text { Chestnut Leek- } \\
\text { Orchid }\end{array}$ & Orchidaceae & endangered & $\begin{array}{l}\text { Critically } \\
\text { Endangered }\end{array}$ & Bruny Island \\
\hline Prasophyllum secutum & $\begin{array}{l}\text { Northern Leek- } \\
\text { Orchid }\end{array}$ & Orchidaceae & endangered & Endangered & $\begin{array}{l}\text { Cape Barren Island, Flinders Island; } \\
\text { Hunter Island; Robbins Island }\end{array}$ \\
\hline Pterostylis cucullata & Leafy Greenhood & Orchidaceae & endangered & Vulnerable & $\begin{array}{l}\text { King Island; Hunter Island; Three } \\
\text { Hummock Island; Flinders Island }\end{array}$ \\
\hline Pterostylis lustra & $\begin{array}{l}\text { Small Sickle } \\
\text { Greenhood }\end{array}$ & Orchidaceae & endangered & & Perkins Island \\
\hline Pterostylis sanguinea & Banded Greenhood & Orchidaceae & rare & & $\begin{array}{l}\text { Cape Barren Island; Clarke Island; } \\
\text { Flinders Island; Deal Island }\end{array}$ \\
\hline Pterostylis squamata & Ruddy Greenhood & Orchidaceae & vulnerable & & Bruny Island \\
\hline Pterostylis tunstallii & $\begin{array}{l}\text { Tunstalls } \\
\text { Greenhood }\end{array}$ & Orchidaceae & endangered & & $\begin{array}{l}\text { Vansittart Island; Flinders Island; } \\
\text { Swan Island }\end{array}$ \\
\hline Ranunculus diminutus & Brackish Buttercup & Ranunculaceae & endangered & & Badger Island \\
\hline $\begin{array}{l}\text { Ranunculus pumilio } \\
\text { var. pumilio }\end{array}$ & Ferny Buttercup & Ranunculaceae & rare & & Flinders Island \\
\hline Scaevola albida & Pale Fanflower & Goodeniaceae & vulnerable & & Flinders Island \\
\hline Schenkia australis & Spike Centaury & Gentianaceae & rare & & $\begin{array}{l}\text { Hunter Island; Three Hummock } \\
\text { Island; Cape Barren Island; Flinders } \\
\text { Island }\end{array}$ \\
\hline $\begin{array}{l}\text { Schoenoplectus } \\
\text { tabernaemontani }\end{array}$ & River Clubsedge & Cyperaceae & rare & & Flinders Island; King Island \\
\hline Schoenoplectus validus & River Clubsedge & Cyperaceae & rare & & King Island \\
\hline Schoenus brevifolius & Zigzag Bogsedge & Cyperaceae & rare & & Bruny Island \\
\hline Scleranthus fasciculatus & Spreading Knawel & Caryophyll-aceae & vulnerable & & Flinders Island; Bruny Island \\
\hline Scutellaria humilis & Dwarf Skullcap & Lamiaceae & rare & & Maria Island \\
\hline Senecio psilocarpus & Swamp Fireweed & Asteraceae & endangered & Vulnerable & Flinders Island; King Island \\
\hline Senecio squarrosus & Leafy Fireweed & Asteraceae & rare & & Partridge Island; Bruny Island \\
\hline Sicyos australis & Star Cucumber & Cucurbitaceae & rare & & Inner Sister Island; Outer Sister Island \\
\hline Solanum opacum & $\begin{array}{l}\text { Greenberry } \\
\text { Nightshade }\end{array}$ & Solanaceae & endangered & & $\begin{array}{l}\text { Deal Island; Kent Group; Prime Seal } \\
\text { Island; Inner Sister Island; King Island }\end{array}$ \\
\hline $\begin{array}{l}\text { Spyridium parvifolium } \\
\text { var. molle }\end{array}$ & Soft Dustymiller & Rhamnaceae & rare & & $\begin{array}{l}\text { Flinders Island; Cape Barren Island; } \\
\text { Clarke Island }\end{array}$ \\
\hline $\begin{array}{l}\text { Spyridium parvifolium } \\
\text { var. parvifolium }\end{array}$ & Coast Dustymiller & Rhamnaceae & rare & & Flinders Island; Cape Barren Island \\
\hline $\begin{array}{l}\text { Spyridium vexilliferum } \\
\text { var. vexilliferum }\end{array}$ & Helicopter Bush & Rhamnaceae & rare & & $\begin{array}{l}\text { Prime Seal Island; Flinders Island; } \\
\text { Schouten Island }\end{array}$ \\
\hline $\begin{array}{l}\text { Stellaria multiflora } \\
\text { subsp. nebulosa }\end{array}$ & $\begin{array}{l}\text { Nebulous Rayless } \\
\text { Starwort }\end{array}$ & Caryophyllaceae & rare & & $\begin{array}{l}\text { Deal Island; Curtis Island; Flinders } \\
\text { Island; Vansittart Island; Little Dog } \\
\text { Island; Swan Island }\end{array}$ \\
\hline
\end{tabular}


APPENDIX 2 - cont.

\begin{tabular}{|c|c|c|c|c|c|}
\hline Species name 3 & Common name & Family 3 & $\begin{array}{l}\text { Status }^{2} \\
\text { TAS }\end{array}$ & $\begin{array}{l}\text { Status }^{2} \\
\text { CW }\end{array}$ & Island or group \\
\hline Stuckenia pectinata & Fennel Pondweed & $\begin{array}{l}\text { Potamogeton- } \\
\text { aceae }\end{array}$ & rare & & $\begin{array}{l}\text { Flinders Island; Cape Barren Island; } \\
\text { Clarke Island }\end{array}$ \\
\hline Stylidium beaugleholei & $\begin{array}{l}\text { Blushing } \\
\text { Triggerplant }\end{array}$ & Stylidiaceae & rare & & $\begin{array}{l}\text { King Island; Flinders Island; Cape } \\
\text { Barren Island; Flinders Island }\end{array}$ \\
\hline Stylidium despectum & $\begin{array}{l}\text { Blushing } \\
\text { Triggerplant }\end{array}$ & Stylidiaceae & rare & & $\begin{array}{l}\text { King Island; Flinders Island; Clarke } \\
\text { Island }\end{array}$ \\
\hline Stylidium perpusillum & Tiny Triggerplant & Stylidiaceae & rare & & $\begin{array}{l}\text { King Island; Cape Barren Island; } \\
\text { Clarke Island }\end{array}$ \\
\hline Taraxacum cygnorum & Coast Dandelion & Asteraceae & & Vulnerable & Prime Seal Island; Flinders Island \\
\hline Teloschistes flavicans & Golden-Hair Lichen & Teloschistaceae & rare & & $\begin{array}{l}\text { Inner Sister Island; Outer Sister } \\
\text { Island; Babel Island }\end{array}$ \\
\hline Teucrium corymbosum & Forest Germander & Lamiaceae & rare & & Bruny Island \\
\hline Teucrium corymbosum & Forest Germander & Lamiaceae & rare & & Maria Island; Bruny Island \\
\hline Thelymitra antennifera & Rabbit Ears & Orchidaceae & endangered & & Hunter Island \\
\hline Thelymitra atronitida & $\begin{array}{l}\text { Blackhood Sun- } \\
\text { Orchid }\end{array}$ & Orchidaceae & endangered & & Bruny Island; Cape Barren Island \\
\hline $\begin{array}{l}\text { Thelymitra } \\
\text { benthamiana }\end{array}$ & $\begin{array}{l}\text { Blotched Sun- } \\
\text { Orchid }\end{array}$ & Orchidaceae & endangered & & Flinders Island \\
\hline Thelymitra holmesii & $\begin{array}{l}\text { Bluestar Sun- } \\
\text { Orchid }\end{array}$ & Orchidaceae & rare & & $\begin{array}{l}\text { King Island; Bruny Island; Cape } \\
\text { Barren Island; Flinders Island }\end{array}$ \\
\hline Thelymitra improcera & Coast Sun-Orchid & Orchidaceae & endangered & & King Island \\
\hline Thelymitra jonesii & Skyblue Sun-Orchid & Orchidaceae & endangered & Endangered & $\begin{array}{l}\text { Schouten Island; Cape Barren Island; } \\
\text { Bruny Island }\end{array}$ \\
\hline Thelymitra malvina & $\begin{array}{l}\text { Mauvetuft Sun- } \\
\text { Orchid }\end{array}$ & Orchidaceae & endangered & & $\begin{array}{l}\text { Hunter Island; Three Hummock } \\
\text { Island; Robbins Island; Cape Barren } \\
\text { Island; Flinders Island }\end{array}$ \\
\hline Thelymitra mucida & Plum Sun-Orchid & Orchidaceae & $\begin{array}{l}\text { rare } \\
\text { (unofficial), } \\
\text { listing as } \\
\text { endangered } \\
\text { pending }\end{array}$ & & Bruny Island; Flinders Island \\
\hline $\begin{array}{l}\text { Thynninorchis } \\
\text { huntiana }\end{array}$ & Elbow Orchid & Orchidaceae & extinct & & Flinders Island \\
\hline Tmesipteris parva & Small Forkfern & Psilotaceae & vulnerable & & Flinders and King Islands \\
\hline Tricostularia pauciflora & Needle Bogsedge & Cyperaceae & rare & & Cape Barren Island; Schouten Island \\
\hline Triglochin minutissima & Tiny Arrowgrass & Juncaginaceae & rare & & $\begin{array}{l}\text { Erith Island; Flinders Island; Clarke } \\
\text { Island; Forsyth Island; King Island }\end{array}$ \\
\hline Triglochin mucronata & Prickly Arrowgrass & Juncaginaceae & endangered & & Vansittart Island; Flinders Island \\
\hline Trithuria submersa & $\begin{array}{l}\text { Submerged } \\
\text { Watertuft }\end{array}$ & Hydatellaceae & rare & & Cape Barren Island; King Island \\
\hline Utricularia australis & Yellow Bladderwort & Lentibulariaceae & rare & & Flinders Island; Bruny Island \\
\hline Utricularia tenella & Pink Bladderwort & Lentibulariaceae & rare & & $\begin{array}{l}\text { King Island; Clarke Island; Cape } \\
\text { Barren Island; Flinders Island }\end{array}$ \\
\hline Utricularia violacea & Violet Bladderwort & Lentibulariaceae & rare & & Flinders Island \\
\hline Velleia paradoxa & Spur Velleia & Goodeniaceae & vulnerable & & Bruny Island \\
\hline Vittadinia muelleri & $\begin{array}{l}\text { Narrowleaf New- } \\
\text { Holland-Daisy }\end{array}$ & Asteraceae & rare & & Bruny Island; Maria Island \\
\hline Wilsonia humilis & Silky Wilsonia & Convolvulaceae & rare & & Flinders Island \\
\hline
\end{tabular}


106 Sally L. Bryant and Stephen Harris

APPENDIX 2 - cont.

\begin{tabular}{|c|c|c|c|c|c|}
\hline Species name ${ }^{3}$ & Common name & Family 3 & $\begin{array}{l}\text { Status }^{2} \\
\text { TAS }\end{array}$ & $\begin{array}{c}\text { Status }^{2} \\
\text { CW }\end{array}$ & Island or group \\
\hline Wilsonia rotundifolia & Roundleaf Wilsonia & Convolvulaceae & rare & & Deal Island; Cape Barren Island \\
\hline $\begin{array}{l}\text { Xanthoparmelia } \\
\text { microphyllizans }\end{array}$ & Lichen & Parmeliaceae & rare & & Deal Island \\
\hline Xerochrysum bicolor & Eastcoast Paperdaisy & Asteraceae & rare & & Mount Chappell Island; Maria Island \\
\hline $\begin{array}{l}\text { Zygophyllum } \\
\text { billardierei }\end{array}$ & Coast Twinleaf & Zygophyllaceae & rare & & Flinders Island; Prime Seal Island \\
\hline
\end{tabular}

1 Species listed were generated from the Natural Values Atlas (Department of Primary Industries, Water and Environment: DPIPWE) which relies on multiple sources both Herbarium vouchered and observational. The information was accessed on 30 October 2020 . The Threatened Species Section (DPIPWE) should be consulted for up to date status, especially for those taxa whose status is listed as "pending" or "unofficial".

2 Tasmanian status is in accordance with listings under the Threatened Species Protection Act 1995. National status (Status CW) refers to listings under the Environment Protection and Biodiversity Conservation Act 1999.

3 Nomenclature of species and family follows de Salas \& Baker (2018). 